\title{
Numerical modelling of sediment transport in the Adriatic Sea
}

\author{
A. Guarnieri ${ }^{1}$, A. J. Souza ${ }^{2}$, N. Pinardi ${ }^{3,4}$, and P. Traykovski ${ }^{5}$ \\ ${ }^{1}$ Istituto Nazionale di Geofisica e Vulcanologia, Sezione di Bologna, Via D. Creti, 12, \\ 40128 Bologna, Italy \\ ${ }^{2}$ National Environment Research Council, Joseph Proudman Building, 6 Brownlow Street, \\ Liverpool, UK \\ ${ }^{3}$ Department of Physics, University of Bologna, viale Berti Pichat, 6/2, 40127 Bologna, Italy \\ ${ }^{4}$ Centro EuroMediterraneo sui Cambiamenti Climatici, Viale A. Moro 44, 40127 Bologna, Italy \\ ${ }^{5}$ Woods Hole Oceanographic Institution, 266 Woods Hole Road, Woods Hole, \\ MA 02543-1050, USA
}

Received: 4 April 2014 - Accepted: 25 April 2014 - Published: 6 June 2014

Correspondence to: A. Guarnieri (antonio.guarnieri@bo.ingv.it)

Published by Copernicus Publications on behalf of the European Geosciences Union.

Numerical modelling of sediment transport in the Adriatic Sea

A. Guarnieri et al.

\section{Title Page}

\section{Abstract}

Introduction

Conclusions

References

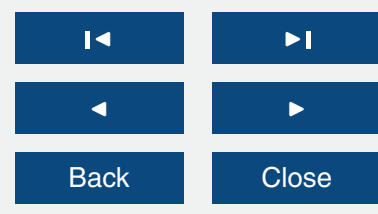

Full Screen / Esc

Printer-friendly Version

Interactive Discussion 


\section{Abstract}

A new sediment transport model, considering currents, tides and waves is presented for the Adriatic Sea basin. The simulations concentrate on the winter of 2002-2003 because of field data availability and interesting intermittent processes occurrence.

5 A process oriented analysis is performed to investigate the impact that Sirocco and Bora wind regimes have on sediment transport.

The comparisons of the simulations with the observed data show that the model is capable to capture the main dynamics of sediment transport along the Italian coasts and the sediment concentration within the water column. This latter can reach values 10 up to several $\mathrm{g} \mathrm{L}^{-1}$, especially within the first centimetres above the bottom. The sediments are transported mainly southwards along the Italian coasts, consistently with the known literature results, except during Sirocco wind events, which can be responsible for reversing the coastal circulation in the northern area of the basin, and consequently the sediment transport. The resuspension of sediments is also related to the specific 15 wave regimes induced by Bora and Sirocco, the former inducing resuspension events near the coasts while the latter causing a more diffused resuspension regime in the Northern Adriatic basin.

Beside the realistic representation of short timescales resuspension/deposition events due to storms, the model was also used to investigate persistent erosion or deposition areas in the Adriatic Sea. Two main depocenters were identified: one, very pronounced, in the surroundings of the Po river delta, and another one a few kilometres off the coast in front of the Ancona promontory. A third region of accumulation, even if less intense, was found to be offshore the southernmost limit of the Gargano region. On the contrary the whole western coast within a distance of a few kilometres from 25 the shore was found to be subject to prevailing erosion. The comparison with observed accumulation and erosion data shows that the model captures well the main depocenters in the domain and the erosion within the very coastal belt of the western side of the basin, but seems to be too erosive in a few areas, in particular those where the
OSD

$11,1391-1433,2014$

Numerical modelling of sediment transport in the Adriatic Sea

A. Guarnieri et al.

\section{Title Page}

Abstract Introduction

Conclusions References

Tables Figures

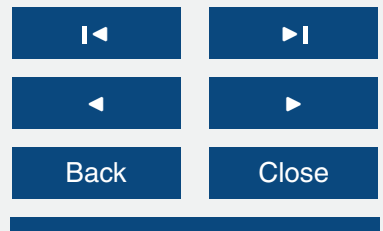

Full Screen / Esc

Printer-friendly Version

Interactive Discussion 
contribution of sediment inflow to the sea of some minor but intermittently important rivers is not considered in a realistic way as input to the model.

\section{Introduction}

A runoff influenced area such as the Adriatic Sea has always attracted the interest in 5 sediment transport. Sediments are fundamental vehicles for the transport of pollutants at sea (Frascari et al., 1998), and their concentration in the water column strongly influences the penetration of light, impacting the physical properties of the water and also the growth of phytoplankton in the upper parts of the water column (Vichi et al., 1998). The sediment transport is of major importance for coastal protection and coastal engineering in general, for sand mining at sea, or simply for tourism and recreational purposes (Warren and Johnsen, 1993).

The north-western part of the Adriatic Sea (Fig. 1) is characterized by sandy coasts, thus affected by sediment movements, and by many rivers runoff. Among them the Po river is an important source of solid materials for both the seabed and the water 15 column, after resuspension. The motion of the fluid over the sea bottom interface creates a shear proportional to the intensity of the motion which can be responsible of the movement of the sediment grains previously deposited. This happens when the shear exceeds a certain critical value for erosion. Resuspension involves directly the bottom boundary layer and its characteristics, in relation with the fluid motion, giving rise

to highly non-linear friction processes, whose degree of complexity is closely related to the mechanisms that drive the motion itself, i.e. tides, waves, wind currents, density gradient currents (Grant and Madsen, 1986). It is now known that the short wind wave motion, together with currents, is responsible for an increase in the bottom friction (Smith, 1977; Grant and Madsen, 1979; Cacchione and Drake, 1982; Grant et al., 1984;

Frignani et al. (2005) showed that the most important depositional pattern in the Adriatic Sea is found all around the Po river delta, presenting accumulation rates up

OSD

$11,1391-1433,2014$

Numerical modelling of sediment transport in the Adriatic Sea

A. Guarnieri et al.

\section{Title Page}

Abstract Introduction

Conclusions References

Tables Figures

14

4

Back

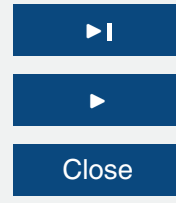

Full Screen / Esc

Printer-friendly Version

Interactive Discussion 
to $2 \mathrm{~cm} \mathrm{yr}^{-1}$, also in agreement with Ravaioli et al. ("Bioturbazione e veloctà di sedimentazione", scientific report from PRISMA PROJECT), or up to $6 \mathrm{~cm} \mathrm{yr}^{-1}$ according to Palinkas (2005). Two other important depositional areas are found a few kilometres offshore the Ancona and the Gargano promontory, with accumulation rates ranging 5 from 0.15 to $0.60 \mathrm{~g} \mathrm{~cm}^{-2} \mathrm{yr}^{-1}$.

Wang and Pinardi (2002) showed that the two major Adriatic wind regimes, the Bora and Sirocco winds, play a crucial role in the sediment distribution through the wave induced motion. Sirocco is a southerly wind and it has a much longer fetch than Bora (which is a north-easterly wind). Sirocco generates waves with typical periods up to 10 9-10 s, in contrast with Bora wind generated waves whose typical periods are about $5 \mathrm{~s}$. This implies that less intense Sirocco winds can generate waves whose significant heights and bottom orbital velocities can be comparable with those generated by more intense Bora winds (Wang and Pinardi, 2002). The winds also induce different currents: Bora tends to intensify the southward circulation, so-called the Western Adri15 atic Coastal Current (WACC, Zavatarelli and Pinardi, 2003), while Sirocco events can weaken or even reverse the southward currents, confining the sediment in the northernmost area of the basin.

Wang and Pinardi (2002) through idealized process studies on the basin were able to assess the most relevant processes in the sediment transport of the north-western 20 Adriatic Sea area and to determine their relative importance. They argued that the maximum southward sediment flux occurs under Bora conditions and it exceeds the Sirocco induced flux by approximately a factor 4 at a cross section south of the Po river delta. On the other hand, northward sediment flux was maximum under Sirocco wave conditions and on a river plume driven circulation. Finally, in idealized conditions 25 of wind generated waves acting on a river and wind driven circulation the sediment transport resulted southwards both to the north and to the south of the Po river delta under both Bora and Sirocco. Also Bever et al. (2009) carried on process studies under idealized conditions in the same area and found partially different results. In fact they found that under steady wind conditions the sediment transport was always southwards
OSD

11, 1391-1433, 2014

Numerical modelling of sediment transport in the Adriatic Sea

A. Guarnieri et al.

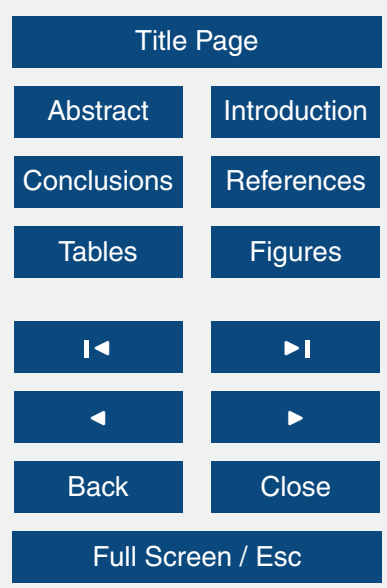

Printer-friendly Version

Interactive Discussion 
but the Bora associated flux was lower by approximately three times if compared to the one associated with Sirocco. Moreover they report a northward sediment flux only under unsteady Sirocco conditions and in a section to the north of the Po river. As already suggested by Bever et al. (2009) these differences may be due to the fact that 5 Wang and Pinardi (2002) studied only steady wind conditions and used fair-weather conditions, while Bever et al. focused on much more severe wave and wind conditions.

The same authors also performed simulations under realistic conditions, albeit for different periods and focusing on different processes. At a section south of the Po river Wang and Pinardi (2002) found a prevailing costal flux heading north under Sirocco 10 and river flood conditions, and a strong southward flux under Bora conditions. Bever et al. (2009) argue that the highest transport rate away from the Po river mouth occurs during Bora events, and that the temporal variations of the wind field resulted in northward transports coinciding with strong Sirocco conditions, which partially corroborates the results of Wang and Pinardi (2002) under realistic conditions.

Finally Wang et al. (2006) showed in the same domain the fundamental importance of the interaction between wave orbital velocities and currents in the bottom boundary layer (BBL), arguing, on the contrary, that the tidal forcing produces small effects in sediment transport processes in the Northern Adriatic Sea.

In this paper we will consider all transport fields, from tides to wind currents and 20 wave-induced velocities.

The purpose of this paper is to the sedimentation structures generated by a currentwave-tides hydrodynamic model coupled with a sediment transport model where a new sea-bed parameterization for resuspension is used. The aim is to understand the mechanisms that control the fine and coarse grain sediment distribution in the north-western

25 Adriatic Sea and finally to contrast the pattern of sediment concentrations and fluxes to observational evidence. For this purpose we referred to consolidated literature, recalling in particular the work of Frignani et al. (2005) for the analysis of depositional patterns and sediment pathways in the whole domain, and to the observed data on sediment concentration and transport recorded during the EUROSTRATAFORM project at
OSD

11, 1391-1433, 2014

Numerical modelling of sediment transport in the Adriatic Sea

A. Guarnieri et al.

Title Page

Abstract Introduction

Conclusions References

Tables Figures

14

4

Back

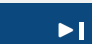

$>$

Close

Full Screen / Esc

Printer-friendly Version

Interactive Discussion 
the WHOI tripod (Traykovski et al., 2007), deployed south of the Po river mouth in 2002, in an area very sensitive to sediment movements (green dot of Fig. 1).

The paper is structured as follows: Sect. 2 describes the wave model and the sediment transport sub-model coupled with the ocean general circulation model including 5 tides, for which a brief overview is also given. In Sect. 3 the experiment set-up is described, while the corresponding results are discussed in Sect. 4 together with validation against observations. In Sect. 5 a summary of the work and some conclusions are proposed.

\section{Description of the coupled physical and sediment trasport model}

10 As anticipated in Sect. 1 the wave activity is the major factor for the resuspension of sediments along the water column, so a realistic representation of waves is fundamental to be able to reproduce accurately the sediment dynamics at sea. After giving a summary of the circulation model used, the following subsections describe the wave and sediment models used in this work.

\subsection{The baroclinic ocean circulation model with tides}

The circulation model we used is the one presented by Guarnieri et al. (2013). It is an implementation of the Princeton Ocean Model (POM, Blumberg and Mellor, 1987) covering the entire Adriatic Sea (Fig. 1) and presenting a lateral open boundary line at $39^{\circ} \mathrm{N}$, where it is nested into the operational Mediterranean Forecasting System (MFS) model (Pinardi et al., 2003; Tonani et al., 2008). The horizontal resolution is approximately $1 / 45^{\circ}$ and it is resolved on 31 vertical sigma layers. The vertical mixing coefficients are provided by a second-order turbulence closure sub-model (Mellor and Yamada, 1982), the horizontal viscosity is parameterized following the scheme of Smagorinsky (1993), while the advection part of the hydrodynamics equations is solved through a Monotonic Up-Stream Scheme for Conservation Law (MUSCL - Estubier

OSD

11, 1391-1433, 2014

Numerical modelling of sediment transport in the Adriatic Sea

A. Guarnieri et al.

\section{Title Page}

Abstract Introduction

Conclusions References

Tables Figures

14

4

Back

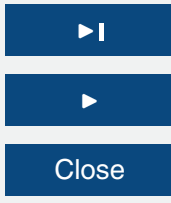

Full Screen / Esc

Printer-friendly Version

Interactive Discussion 
and Lévy, 2000). The air-sea interaction is calculated through bulk formulae from the atmospheric forcings, which are the reanalyses of the European Centre of Medium Range Weather Forecast (ECMWF) at a horizontal resolution of $0.5^{\circ}$, available every $6 \mathrm{~h}$. In particular the long wave radiation flux is computed through the formula proposed 5 by May (1986), the latent and sensible heat fluxes are calculated according to Kondo (1975), and the wind stress on the surface of the sea is computed through the formulation of Hellerman and Rosenstein (1983). The rain water input is the climatological dataset from Legates and Willmott (1990), while the rivers runoff, except for the Po and the Buna/Bojana river, are taken from the climatology of Raicich's, 1994. The Po river

10 flow values used will be discussed in Sect. 3, while the Buna/Bojana river climatological flow values of Raicich's have been replaced by those recently proposed by Marini et al. (2010). Through a modified Flather boundary condition (Oddo and Pinardi, 2008) at the open boundary line the circulation model also accounts for tides, which can not be neglected in the Adriatic Sea basin (Guarnieri et al., 2013).

\subsection{The wave model}

The model used for simulating the wave field is SWAN (Simulating WAves Nearshore, Holthuijsen et al., 1989; Booij et al., 1999; Ris et al.,1999; SWAN team, 2010), a third generation spectral wave model developed by the Delft Univeristy of Technology. The model is based on the spectral action balance equation, and it imposes no limitations on the spectrum to affect the growth of the wave. The effects taken into account by this model are spatial propagation, refraction, shoaling generation, dissipation and non linear interactions (see "SWAN scientific and technical documentation"). The model has been implemented on the Adriatic Sea domain of the Adriatic REGional model described in Guarnieri et al. (2013) using the same lon/lat grid, with a horizontal res-

olution of approximately $2.2 \mathrm{~km}$, and the same bathymetry. The wave directions have been discretized by 36 bins of $10^{\circ}$ each. The model has been run in stationary mode, under the ECMWF analysis atmospheric forcings at a horizontal resolution of $0.5^{\circ}$, and at the frequency of $6 \mathrm{~h}$. We are aware that these temporal and spatial resolutions are

OSD

$11,1391-1433,2014$

Numerical modelling of sediment transport in the Adriatic Sea

A. Guarnieri et al.

\section{Title Page}

Abstract Introduction

Conclusions References

Tables Figures

14

4

Back

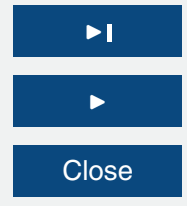

Full Screen / Esc

Printer-friendly Version

Interactive Discussion 
not the most adequate for the reproduction of coastal non linear processes such as wind wave generation and sediment transport. In fact it is known (Cavaleri and Bertotti, 2004) that the bias between observed and modelled wind velocity rapidly decreases with the use of higher resolution. This is particularly evident close to coast, which is the 5 region of main interest of sediment transport phenomena, as well as the area mainly affected by the errors in the wind reproduction by atmospheric models. In these areas, predominant in small enclosed basins such as the Adriatic Sea the reproduced wind speeds are almost always underestimated, and the bias depends on the vicinity of land (Cavaleri and Bertotti, 1997), and it is also strictly related to the fetch: the shorter the 10 fetch, the bigger the errors (Cavaleri and Bertotti, 2004). This has an important implication in the reproduction of the two typical wind regimes of the Adriatic Sea, the Bora and the Sirocco, meaning relatively bigger errors in Bora than in Sirocco events. The errors in the wave fields follow accordingly, and they are higher than those in the winds in terms of percentage since the involved processes are strongly non linear (Cavaleri 15 and Bertotti, 2004). Furthermore waves have longer memory than winds so they tend to persist for longer distances (Cavaleri and Bertotti, 2004).

In spite of the wind coarse resolution the results of the wave model in the location of the WHOI tripod are fairly good, as we will show further on, so we believe they are suitable for the present study.

For the computation of the bottom friction the Madsen scheme (1988) was used in the wave model, assuming the default value for the equivalent bottom roughness length scale. The wave parameters calculated with the SWAN model and necessary to the coupling with the current model were the wave period and direction and the wave bottom orbital velocity. The latter is the most important field in order to evaluate the maximum bottom shear stress due to the combined action of waves and currents. It can be shown that its distribution along the water column for a monochromatic wave, using linear theory, is given by:

$u(z)=\eta_{0} \omega \frac{\cosh (k(z+H))}{\sinh (k H)} \cos (k x-\omega t)$
OSD

11, 1391-1433, 2014

Numerical modelling of sediment transport in the Adriatic Sea

A. Guarnieri et al.

Title Page

Abstract Introduction

Conclusions References

Tables Figures

14

4

Back

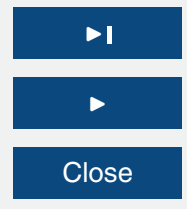

Full Screen / Esc

Printer-friendly Version

Interactive Discussion 
where $\eta_{0}$ is the wave amplitude, $\omega$ is the radian or circular frequency, $k$ is the wave number, $H$ is the water depth, and $z$ and $x$ are respectively the vertical and horizontal component in a Cartesian coordinates system. The amplitude of the orbital velocity varies sinusoidally in time, reaching its minimum when $k x-\omega t= \pm \frac{n \pi}{2}$, and its maximum 5 when $k x-\omega t= \pm n \pi$. In the framework of sediment resuspension and transport, we are interested in the maximum bottom shear stress, thus in the maximum value of $u$ at $z=-H$, so Eq. (1) becomes:

$u_{\text {bott }}^{\prime}=\frac{\eta_{0} \omega}{\sinh (k H)}$

10 Real waves are not monochromatic, so Eq. (2) for a realistic wave becomes:

$u_{\text {bott }}=\sqrt{2}\left(\int_{0}^{2 \pi} \int_{0}^{+\infty} \frac{\omega^{2}}{\sinh ^{2}(k H)} S(\omega, \theta) \mathrm{d} \omega \mathrm{d} \theta\right)^{\frac{1}{2}}$

where $S$ is the wave spectrum distributing the energy over directions $\theta$ and frequencies $\omega$. In sediment transport, representative wave bottom velocities are usually referred to, 15

$u_{\mathrm{w}}=\frac{u_{\mathrm{bott}}}{\sqrt{2}}$

Figure 2 presents the validation of the wave model in the WHOI tirpod location (Traykovski et al., 2007), close to the Po river delta. The bathymetry of the site is ap20 proximately $13 \mathrm{~m}$. The data presented are the representative bottom orbital velocities $u_{\mathrm{w}}$. The black line represents observations, while the red line represents simulations. $\mathrm{HC}_{i}$ and $\mathrm{DS}_{i}$ refer respectively to high concentration (turbidity flow) and diluted suspension events of sediment transport, as classified by Traykovski et al. (2007). Since the work of Traykovski et al. (2007) is frequently referred to in this paper, we maintained 1399

\section{OSD}

11, 1391-1433, 2014

Numerical modelling of sediment transport in the Adriatic Sea

A. Guarnieri et al.

\section{Title Page}

Abstract Introduction

Conclusions References

Tables Figures

14

4

Back

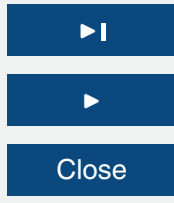

Full Screen / Esc

Printer-friendly Version

Interactive Discussion 
the same notation and classification of the significant wind and wave events. $\mathrm{HC} 1, \mathrm{HC} 2$ and $\mathrm{HC} 3$ events are high concentration events. Amongst them $\mathrm{HC} 1$ and $\mathrm{HC} 2$ were generated by Sirocco winds, while HC3 originated by Bora wind. The diluted suspension events DS1 to DS4 were all generated by Bora winds. The details of events HC1 and 5 DS1 will be discussed later in the paper, in order to analyze the different mechanisms of sediment transport resulting from Sirocco and Bora events respectively.In spite of the coarseness of the wind field forcing the SWAN model, both in time and space, the response of the model appears to be fairly good (Fig. 2), even if some overestimation of the medium amplitude peaks is evident, particularly in the period between January 10 and March 2003. Also event HC3 is overestimated by the model. The fact that these events tend to be overestimated in spite of the poor resolution of the forcings and of the vicinity to the coastline can probably be explained by the fact that the measured bathymetry of this site is $13 \mathrm{~m}$, while it is $10.7 \mathrm{~m}$ in the model. This probably overcomes the known underestimation of wind intensity by the ECMWF wind field.

\subsection{The sediment transport sub-model}

The sediment transport sub-model is based on the equation of advection-diffusion for a passive tracer in an incompressible fluid:

$\frac{\partial C}{\partial t}+\frac{\partial}{\partial x}(u C)+\frac{\partial}{\partial y}(v C)+\frac{\partial}{\partial z}\left[\left(w+w_{\mathrm{s}}\right) C\right]=\frac{\partial}{\partial z}\left(K_{\mathrm{v}} \frac{\partial C}{\partial z}\right)+A_{\mathrm{M}} \nabla_{h}^{2} C$

20 where $x, y, z$ are the spatial coordinates of a Cartesian system, and the corresponding velocity components are $\boldsymbol{u}=(u, v, w) . C$ is the concentration of the sediment suspended along the water column, while $K_{\mathrm{v}}$ and $A_{\mathrm{M}}$ are respectively the vertical mixing coefficient and eddy viscosity, which do not differ from those used for the diffusion of salt and heat. $K_{\mathrm{v}}$ is given by the turbulence closure sub-model of Mellor-Yamada 2.5 25 (1982). As a simplification we assume that the enhanced density due to the suspended sediment along the water column does not have any impact on the hydrodynamics of the circulation model. As we will see later in the paper though, this might imply some 1400

\section{OSD}

11, 1391-1433, 2014

Numerical modelling of sediment transport in the Adriatic Sea

A. Guarnieri et al.

\section{Title Page}

Abstract Introduction

Conclusions References

Tables Figures

14

4

Back

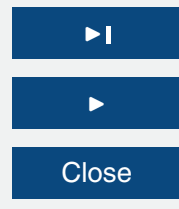

Full Screen / Esc

Printer-friendly Version

Interactive Discussion 
overestimation of sediment concentration in the upper parts of the water column since the reduction of the eddy viscosity due to sediment density stratification is not accounted for. The term $w_{\mathrm{s}}$ in Eq. (5) represents the sediment settling velocity. It can be estimated by means of the Stokes law as it follows:

${ }_{5} \quad w_{\mathrm{s}}=\frac{g d^{2}}{18 v}\left(\frac{\rho_{\mathrm{s}}}{\rho_{\mathrm{w}}}-1\right)$

where $\rho\left(\mathrm{kg} \mathrm{m}^{-3}\right)$ is density and the subscripts $\mathrm{s}$ and $\mathrm{w}$ indicate sediment and water respectively, $g\left(\mathrm{~m} \mathrm{~s}^{-2}\right)$ is gravity, $v\left(\mathrm{~m}^{2} \mathrm{~s}^{-1}\right)$ is kinematic viscosity of water, and $d(\mathrm{~m})$ is the mean diameter of the sediment grains.

10 Equation (6) is valid for a sediment concentration that does not affect the water motion and the sediments are assumed not to flocculate, so the model is suitable for non-cohesive sediments.

Equation (5) requires initial, surface and bottom, as well as lateral boundary conditions: while the lateral inflow of sediments at the open boundary in the lonian Sea 15 (Fig. 1) is assumed to be zero, the two vertical boundary conditions are instead to be discussed in details.

The vertical bottom boundary condition for sediment flux can be represented as:

$\left.K_{\mathrm{v}} \frac{\partial C}{\partial z}\right|_{z=-H}-w_{\mathrm{s}} C=S$

20 where $H$ is the water depth, and $S$ is the sediment flux expressed in $\mathrm{kg} \mathrm{m}^{-2} \mathrm{~s}^{-1}$.

The parameterization of $S$ is based on the approach of Ariathurai and Krone (1976) for non-cohesive sediment, based on the concept of critical stresses for deposition and erosion: if the maximum stress at the interface between the sea bed and the sea water is higher than a critical value for erosion we have a flux of sediment from the seabed 25 into the water column (erosion) linearly proportional to the ratio between the bottom maximum stress and the critical stress for erosion itself. Vice versa, we have a flux of
OSD

11, 1391-1433, 2014

Numerical modelling of sediment transport in the Adriatic Sea

A. Guarnieri et al.

\section{Title Page}

Abstract Introduction

Conclusions References

Tables Figures

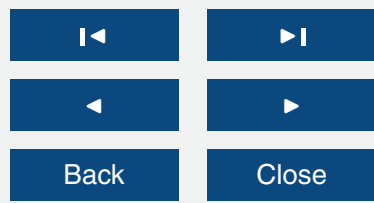

Full Screen / Esc

Printer-friendly Version

Interactive Discussion 
sediment in the opposite direction, from the water column to the seabed (deposition), linearly proportional to the ratio between the bottom maximum stress and a critical stress for deposition. This is also the approach used by Wang and Pinardi (2002) and by Wang et al. (2006). However, we argue that this approach has three main defi5 ciencies: firstly, it introduces a non-physical concept of critical stress for deposition, secondly it does not allow for sediment to be deposited in those periods of time when we have resuspension, as if gravity attraction was not acting due to high bottom shear stresses, and finally there is no limit to erosion, as if the sea bottom were provided with an endless amount of non-compact matter available for resuspension. For these 10 reasons the parameterization used at the bottom boundary was modified with respect to the formulation of Ariathurai and Krone (1976), i.e.:

$S=\left\{\begin{array}{l}S_{0}\left(\frac{\left|\tau_{b}\right|}{\tau_{c}}-1\right) \frac{B_{i}}{\sum_{i=1}^{N} B_{i}} \text { for }\left|\tau_{b}\right|>\tau_{c} \text { and } B_{i}>0 \\ -C_{b} w_{s} \text { for any }\left|\tau_{b}\right|\end{array}\right.$

where $S_{0}\left(\mathrm{~kg} \mathrm{~m}^{2} \mathrm{~s}^{-1}\right)$ is the erodibility of the sea bottom, locally dependent; $\left|\tau_{b}\right|$ and $\tau_{c}$ $15\left(\mathrm{~N} \mathrm{~m}^{-2}\right)$ are the amplitude of maximum bottom shear stress (due to wave, to current, or to their non-linear interaction), and of the critical stress for erosion, respectively. $C_{b}$ is the suspended sediment concentration at the last $\sigma$ layer above the sea bottom, and $w_{\mathrm{s}}$ is the sediment settling velocity $\left(\mathrm{m} \mathrm{s}^{-1}\right) . B_{i}$ is the sediment bed mass $\left(\mathrm{kg} \mathrm{m}^{-2}\right)$ for the $i$ th class amongst the $N$ classes of sediment totally simulated (Souza et al., 2007).

20 In this parameterization there is no dependency from the bottom maximum stress in case of deposition (Eq. 8b), nor from the critical stress of deposition. In fact, as reminded by Amoudry and Souza (2011), the concept of mutual exclusion of erosion and deposition is quite arguable since this paradigm is not supported by any convincing explanations of the physical process (Winterwerp and van Kesteren, 2004), nor ex-

planato

\section{OSD}

$11,1391-1433,2014$

Numerical modelling of sediment transport in the Adriatic Sea

A. Guarnieri et al.

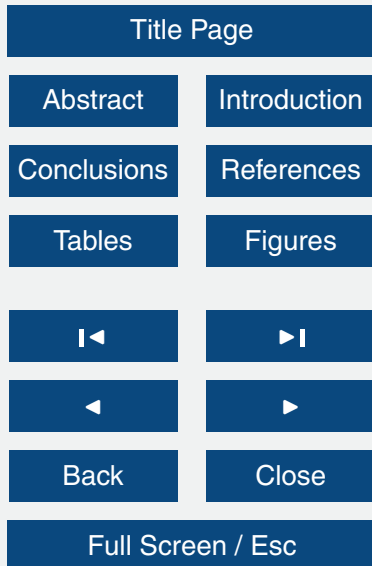

Printer-friendly Version

Interactive Discussion 
sediment bed mass of the $i$ th class of sediment and the total amount of sediment on the bottom. The conservation of each class of sediment mass at the bottom is given by:

$$
\frac{\partial B_{i}}{\partial t}=-\frac{\partial C_{i}}{\partial t} \delta_{b}
$$

where $\delta_{b}$ is the thickness of the last $\sigma$ layer, allowing for deposition and erosion when $B_{i}>0$, and deposition only when $B_{i}=0$ (Souza et al., 2007). This modification allows to limit the sediment flux for each class of sediments only if on the bottom there is available sediment for erosion. Moreover the vertical flux for each one of the classes is proportional to its amount on the sea bottom with respect to the total sediment present.

This approach to the sediment exchange between the water column and the sea bottom is a fairly good compromise between the introduction of a proper sea-bottom sub-model, based on the concept of active layers contributing to the exchange and the complete absence of time-dependency of the flux entering the water column, as it is 15 the case of the Ariathurai and Krone (1976) original parameterization. Compared to more comprehensive and complex approaches such as the one of Harris and Wiberg $(2001,2002)$ our formulation is also able to limit the flux of sediment into the water column related to the availability of solid material, but it is not as sophisticated. First of all our approach is not morphological since the location of the bed surface is invariant 20 in time for us while in the erosion equation used by Harris and Wiberg $(2001,2002)$ the seabed position evolves in time. This evolution takes also into account the gradient of the lateral fluxes of sediment within the bottom boundary layer, thus considering the lateral advective contribution of sediment to conserve the mass, which we omit here. However, considering our interest is not specifically on the morphological evolution of 25 the sea bottom at very high time scales, but it is more focused on the concentration of the sediment along the water column and on its transport around the basin we believe a non-morphological approach is not limiting our study and results. Another difference form Harris and Wiberg's approach is that we do not account for sea bed multi-layering. This means we don't have lower inactive layers eventually feeding the upper layer, nor 1403

\section{OSD}

$11,1391-1433,2014$

Numerical modelling of sediment transport in the Adriatic Sea

A. Guarnieri et al.

\section{Title Page}

Abstract Introduction

Conclusions References

Tables Figures

14

4

Back

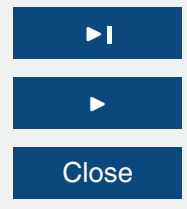

Full Screen / Esc

Printer-friendly Version

Interactive Discussion 
downward movement of the boundary line between different layers due to deposition events. Finally in the approach by Harris and Wiberg (2001) the thickness of the layer of available sediment depends on the grain size and on the intensity of the shear stress, and it is calculated following different approaches for sandy or silty material, which we 5 do not differentiate.

In case of absence of waves the bottom stress $\boldsymbol{\tau}_{\mathrm{b}}$ is due to the near bottom current $u_{\mathrm{c}}$ :

$\boldsymbol{\tau}_{\mathrm{b}}=C_{\mathrm{d}} \rho\left|\boldsymbol{u}_{\mathrm{c}}\right| \boldsymbol{u}_{\mathrm{c}}$

10 With the bottom drag coefficient $C_{\mathrm{d}}$, defined according to Janssen (1991):

$C_{\mathrm{d}}=\max \left\{0.0025 ;\left[\kappa / \ln \left(\frac{\delta_{\mathrm{b}}}{z_{0}}\right)\right]^{2}\right\}$

where $k$ is the von Karman constant, set to $0.40, z_{0}$ is the scale of the bottom roughness, which was here assumed to be $1 \mathrm{~mm}$, and $\delta_{\mathrm{b}}$ is the thickness of the last model 15

level above the bottom. The inferior limit of 0.0025 for $C_{\mathrm{d}}$ is introduced to prevent the bottom drag to be too low in the domain of deep waters.

In the case of currents and waves acting together in the bottom boundary layer, they interact non-linearly, and the resulting bottom maximum shear stress amplitude $\tau_{\mathrm{b}}$ can be estimated through the parameterization of Grant and Madsen (1979):

${ }_{20} \quad \tau_{\mathrm{b}}=\frac{1}{2} f_{\mathrm{cw}} \rho\left(u_{\mathrm{c}}^{2}+u_{\mathrm{w}}^{2}+2 u_{\mathrm{c}} u_{\mathrm{w}} \cos \theta\right)$

where $u_{\mathrm{w}}$ is the amplitude of the representative bottom orbital velocity (see Eq. 4), $\theta$ is the angle between wave and current direction, and $f_{\mathrm{cw}}$ is the wave-current friction factor that takes into account the non linear interaction between currents and waves.

25 The estimate of $f_{\mathrm{cw}}$ can be done through an implicit iterative procedure as proposed by Grant and Madsen (1979) and summarized by Lou et al. (2000).

1404
OSD

$11,1391-1433,2014$

Numerical modelling of sediment transport in the Adriatic Sea

A. Guarnieri et al.

\section{Title Page}

Abstract Introduction

Conclusions References

Tables Figures

14

4

Back

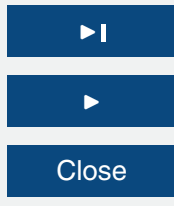

Full Screen / Esc

Printer-friendly Version

Interactive Discussion 
Finally, for what concerns the input of sediment due to the rivers' discharge we used the following surface condition at the rivers' outflow:

$\left.K_{\mathrm{v}} \frac{\partial C}{\partial z}\right|_{z=\eta}=S_{\text {riv }}$

5 where $S_{\text {riv }}$ is the sediment input in $\mathrm{kg} \mathrm{m}^{-2} \mathrm{~s}^{-1}$ supplied by each one of the rivers in the model, and $\eta$ is the elevation of the sea surface. No surface sediment input is considered elsewhere than in the river mouths.

The coupling between the wave model and the sediment transport model happens off-line through the wave bottom orbital velocity, period and direction, which are used 10 in the sediment transport sub-model to calculate the combined bottom stresses. The wave model was run separately from the circulation model, producing fields of wave bottom orbital velocity, period and direction over the whole domain each $6 \mathrm{~h}$, following the ECMWF wind input frequency. These parameters were then linearly interpolated in time at each time-step of the hydrodynamic model. This allows for the computation 15 of the combined bottom shear stress $\tau_{\mathrm{b}}$ every time step of the circulation model. The $\tau_{\mathrm{b}}$ consequently modified has a direct impact on the apparent bottom roughness, $z_{0}$, resulting also in an alteration of the vertical velocity profile.

\section{Numerical experiment design}

The model simulation started on 6 August 2002 and the initial conditions used were 20 taken from a longer model simulation (Guarnieri et al., 2013) without the wave-current-
sediment coupling. In terms of sediments the model was initialized with a sediment
bed mass of $1 \mathrm{~kg} \mathrm{~m}^{-2}$ constant over the whole domain, while the concentration $C$ along the water column was set to $0.002 \mathrm{~kg} \mathrm{~m}^{-3}$ constant in the whole domain. For simplicity two classes of sediments were considered, following Wang and Pinardi (2002) and Wang et al. (2006): a class of finer sediments with a diameter of approximately

\section{OSD}

11, 1391-1433, 2014

Numerical modelling of sediment transport in the Adriatic Sea

A. Guarnieri et al.

\section{Title Page}

Abstract Introduction

Conclusions References

Tables Figures

14

4

Back

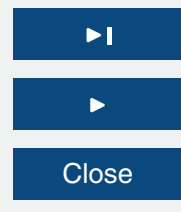

Full Screen / Esc

Printer-friendly Version

Interactive Discussion 
$17 \mu \mathrm{m}$ and a corresponding settling velocity of $10^{-5} \mathrm{~m} \mathrm{~s}^{-1}$, and a coarser class of sediments with a diameter of approximately $55 \mu \mathrm{m}$ and a corresponding settling velocity of $10^{-4} \mathrm{~m} \mathrm{~s}^{-1}$. The critical shear stress for erosion used was $\tau_{\mathrm{c}}=0.02 \mathrm{~Pa}$ for both classes of sediment, and constant in space and time. The erodibility coefficient $S_{0}$ was set to $510^{-6} \mathrm{~kg} \mathrm{~m}^{-2} \mathrm{~s}^{-1}$. This parameter is an empirical constant, and it is strongly locally dependent. Unfortunately we are not aware of measurements taken for the bottom erodibility in the Adriatic Sea, so we used this parameter for the calibration of the model, and the final value used is in the range of the values found in literature, ranging from $10^{-7}$ to $10^{-4} \mathrm{~kg} \mathrm{~m}^{-2} \mathrm{~s}^{-1}$. For what concerns the lateral boundary conditions for sediment 10 the different rivers were treated in a different way. Following the estimate of Frascari et al. (1988) of a total input of sediments from all the Adriatic rivers of approximately $20 \mathrm{Mt} \mathrm{yr}^{-1}$ (20 mega tons per year), and considering that the Po river contributes for about $70 \%$ of this input, we equally spread the remaining $30 \%$ of sediment supply to the other rivers of the basin, estimating a flux of approximately $450 \mathrm{~kg} \mathrm{~s}^{-1}$ for the 15 Po river, and of approximately $6.50 \mathrm{~kg} \mathrm{~s}^{-1}$ for the other rivers. To take into account the great Po river flood occurred in autumn 2002 and winter 2003 which could not be described with climatological values for sediment flux input, this latter was estimated parametrically, linearly depending from the river flow as follows:

$Q_{\mathrm{s}}=\frac{Q_{\mathrm{w}}}{12000}$ for $Q_{\mathrm{w}} \leq 3500 \mathrm{~m}^{3} \mathrm{~s}^{-1}$

20

$Q_{\mathrm{s}}=\frac{Q_{\mathrm{w}}}{5500}$ for $Q_{\mathrm{w}}>3500 \mathrm{~m}^{3} \mathrm{~s}^{-1}$

where $Q_{\mathrm{s}}\left(\mathrm{m}^{3} \mathrm{~s}^{-1}\right)$ is the flow of solid suspended matter, and $Q_{\mathrm{w}}\left(\mathrm{m}^{3} \mathrm{~s}^{-1}\right)$ is the water flow. This was done to try to reproduce the realistic data of concentration used by Bever et al., 2009 (Bever et al., 2009, Fig. 2).

Figure 3 shows the flow and sediment concentration prescribed to the model as boundary conditions for the surface water and sediment fluxes during the period 20022003. The data of flow are the observed values of discharge at the cross section of 1406

\section{OSD}

$11,1391-1433,2014$

Numerical modelling of sediment transport in the Adriatic Sea

A. Guarnieri et al.

\section{Title Page}

Abstract Introduction

Conclusions References

Tables Figures

14

4

Back

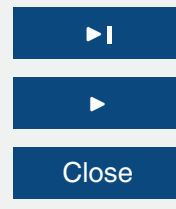

Full Screen / Esc

Printer-friendly Version

Interactive Discussion 
Pontelagoscuro (see black triangle of Fig. 1 for its location), while the data on sediment concentration at the mouths of the Po river (second panel) are the parameterized reconstruction of suspended sediment at the river delta. For the rest of the time the concentration of suspended sediment associated to the Po river was fixed to $450 \mathrm{~kg} \mathrm{~s}^{-1}$.

\section{Model simulations}

\subsection{Winter 2002-2003 simulations}

The sediment model described in the section above has simulated a strong sediment transport event occurred in autumn 2002-winter 2003 and documented in the literature (Traykovski et al., 2007; Fain et al., 2007; Bever et al., 2009). During this period a big 10 flood of the Po river occurred (with flows up to $8000 \mathrm{~m}^{3} \mathrm{~s}^{-1}$ ), as well as several events of Sirocco and Bora, causing very high significant wave heights close to the coast near the Po river. The resulting representative bottom orbital velocities reached values up to $35 \mathrm{~cm} \mathrm{~s}^{-1}$ (Fig. 2). In the same period measurements on sediment concentrations, sediment fluxes, and currents were carried out at the WHOI tripod (Fig. 1) (Traykovski 15 et al., 2007).

One of the most important physical quantity in the sediment model is the bottom stress. Due to the absence of measured data on this parameter, we compared our results with the ones of a 1-D bottom boundary layer model implemented in the Adriatic Sea (Traykovski et al., 2007, panel b Fig. 5), that we can consider as our reference model for bottom stress. Our results are shown in Fig. 4, and refer to the bottom stress estimated at the location of the WHOI tripod (see Fig. 1 for its location).

Figure 4 shows that the model simulates a very similar behavior of the bottom stress if compared to that presented in Traykovski et al. (2007, Fig. 5b). The comparison of the two images shows that some of the events are overestimated by our model, due to the
OSD

$11,1391-1433,2014$

Numerical modelling of sediment transport in the Adriatic Sea

A. Guarnieri et al.

\section{Title Page}

Abstract Introduction

Conclusions References

Tables Figures

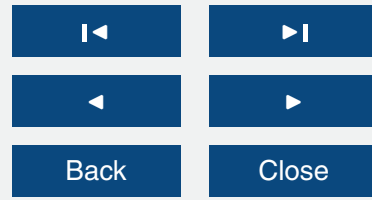

Full Screen / Esc

Printer-friendly Version

Interactive Discussion 
introduced by the low time and space resolution of the atmospheric forcings. In addition the inaccurate bottom bathymetry of the model adds errors to the results.

In the upper panel of Fig. 5 the observed data by Traykovski et al. (2007) are presented, and in the shaded boxes three high concentration events $(\mathrm{HC})$ and four diluted 5 concentration events (DS) are evidenced. The sediment concentration along the water column during the big flood of fall 2002-winter 2003 reached very high values, even up to $60 \mathrm{~g} \mathrm{~L}^{-1}$ during particularly strong storm events, such as the high concentration event occurred on 16 and 17 November, when very strong Sirocco winds generated waves up to $4.5 \mathrm{~m}$ high in the northern part of the basin.

10 The mid and bottom panels represent respectively the simulated coarse and fine sediment concentration along the water column for the same period of time. The first 10 centimeters above the bottom (thereafter called $\mathrm{cm}$ a.b., $\mathrm{cm}$ above the bottom) have been masked out by a dark blue band because the model resolution is not high enough to be able to simulate this region, very close to the bottom, being the thickness of the 15 bottom boundary layer in this location approximately $12 \mathrm{~cm}$. The $\mathrm{HC}$ events are events of very high concentration at the bottom: within the first $5 \mathrm{~cm}$ a.b. several $\mathrm{g} \mathrm{L}^{-1}$ of concentration are found, which the model is not capable to simulate not just because of its resolution but also because we are here in the field of turbidity flows. A more accurate analysis of the observed sediment concentrations vs. the modelled ones underlines immediately some inaccuracies of the model. First of all the predicted coarse sediment concentration is quite consistent with the observations, but if we sum it to the fine sediment concentration the values are too high during no storm periods, and in the upper part of the water column. This might be related to the fact that the observations have been done using an acoustic backscatter (Traykovski et al., 2007), thus they are more sensible to coarse than to fine sediment, but might also have other explanations: on one hand that the model might be too erosive on the finest sediment, which tends always to be suspended along the water column, or that this fine sediment will flocculate and settle. On the other hand that the bottom stresses and the resulting vertical mixing are probably too high. In fact, if we analyze events $\mathrm{HC} 1$ to $\mathrm{HC} 3$, also for coarse sediment,

\section{OSD}

$11,1391-1433,2014$

Numerical modelling of sediment transport in the Adriatic Sea

A. Guarnieri et al.

\section{Title Page}

Abstract Introduction

Conclusions References

Tables Figures

14

4

Back

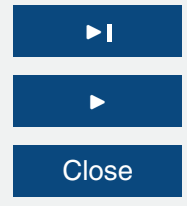

Full Screen / Esc

Printer-friendly Version

Interactive Discussion 
we see that the high concentrations reach too far high along the water column if compared to observations. Moreover the duration of resuspension is often too long, even if, at least for events $\mathrm{HC} 1$ and $\mathrm{HC} 3$, the reason can be addressed to the imprecise wave forcings (Fig. 2). On the contrary, in other cases such as diluted concentration events 5 DS2 and DS3 the model underestimates the concentration of sediment in the lowest part of the water column. This time the reason is quite different, and the analysis of the simulated mass bottom evolution in the location of the tripod for the considered periodhelps understand it, as shown in Fig. 6.

In spite of predicted bottom shear stresses even higher than those predicted by the 10 reference model for bottom stress, the low values of sediment concentrations in these events are due to the unavailability of sediment matter for erosion on the bottom.

As it happens for the sediment concentration, where the modelled coarse class fits best the observations, this happens also for the sediment flux at the tripod WHOI. This is visible from the comparison of the first two panels of Fig. 7 (representing the cumu15 lative depth integrated sediment flux from November 2002 to May 2003) and Fig. 4c of Traykovski et al. (2007), which represents the observed same quantities. The bottom panel of Fig. 7 shows the current regime at $75 \mathrm{~cm}$ a.b. during the same period. Tides have been filtered out. The analysis of Fig. 7 compared to Fig. 4c of Traykovski et al. (2007) hints that the modelled events HC2 and HC3 are definitely not well represented, not only for the overestimation of the flux during the HC3 event, whose reasons have already been analyzed, but mainly because of the hydrodynamic component of the flux: the simulated flux is northward, while the observed one is southward. Starting from the end of the HC3 event, though, the fitting of the data is very good, particularly for what concerns the coarse sediment. In particular, the along shore simulated flux for coarse sediment is $1656 \mathrm{~kg} \mathrm{~cm}^{-1}$ vs. an observed value of approximately $1200 \mathrm{~kg} \mathrm{~cm}^{-1}$ from mid December 2002 to May 2003 (see Fig. 4c of Traykovski et al., 2007).

The cross-shore simulated flux for coarse sediment is slightly positive, while the observed one is slightly negative. If we consider the total sediment (fine plus coarse),
OSD

$11,1391-1433,2014$

Numerical modelling of sediment transport in the Adriatic Sea

A. Guarnieri et al.

Title Page

Abstract Introduction

Conclusions References

Tables Figures

14

4

Back

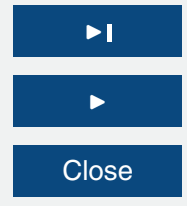

Full Screen / Esc

Printer-friendly Version

Interactive Discussion 
a total southward flux of $3036 \mathrm{~kg} \mathrm{~cm}^{-1}$ is simulated in the same period (excluding the $\mathrm{HC}$ events).

A confirmation of the problems due to hydrodynamics is given in the bottom panel of Fig. 7, representing the along shore (blue line) and cross shore (red line) compo5 nents of the simulated current at $75 \mathrm{~cm}$ above the bottom when compared with Fig. $4 \mathrm{~b}$ of Traykovski et al. (2007), representing the observed same quantities The main differences in the currents are evidenced during event $\mathrm{HC} 3$ and in the days immediately after event DS1. The errors in the simulation of this latter period, are not very significant in terms of fluxes since the suspended sediment was almost negligible. On the contrary, the errors in the representation of the currents during the former event (HC3) are responsible for a very high amount of sediment predicted to flow in the opposite direction to the observed fluxes.

\subsection{Yearly 2003 simulation}

The simulations showed so far were related to very short timescales, of the order of 15

\section{though to also analyze the longer timescale processes, since they can help understand depositional patterns and sediment pathways in the domain.}

hours, such as the processes of sediment erosion for the single events. It is interesting

Figure 8 shows the simulated accumulation rate of sediment in terms of $\mathrm{g} \mathrm{m}^{-2} \mathrm{yr}^{-1}$ from August 2002 to August 2003. It is interesting to compare it to the observed values in Fig. 4 of Frignani et al. (2005). The concentrations in the open sea domain of Fig. 8 have been masked out in the simulation results since Frignani et al. (2005) show concentrations only in this belt. The two main depocenters of the Po river delta and of the Ancona promontory, present in the observations, are very well represented by the model. The majority of the sediments provided by the Po is deposited within the first tens of kilometres around its mouth, reaching high accumulation rates of approximately $1.50 \mathrm{~g} \mathrm{~cm}^{-2} \mathrm{yr}^{-1}$. Another part of the Po and eroded sediments is advected offshore the Ancona promontory, as confirmed by the observations by Frignani et al. (2005). Another
OSD

11, 1391-1433, 2014

Numerical modelling of sediment transport in the Adriatic Sea

A. Guarnieri et al.

\section{Title Page}

Abstract Introduction

Conclusions References

Tables Figures

14

4

Back

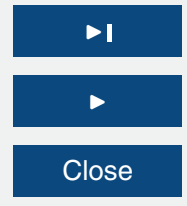

Full Screen / Esc

Printer-friendly Version

Interactive Discussion 
area of accumulation evidenced by the model is found a few kilometres offshore the end of the Gargano Promontory.

The erosion evidenced by the model in the coastal regions between the Po river and Ancona also matches the observations even if this erosion area is too wide in the sim5 ulations, in particular it begins already at $44.5^{\circ} \mathrm{N}$ going south, while in the observations it is evidenced only starting from $44.2^{\circ} \mathrm{N}$, approximately. This may also be due to the lack of sediment inputs from the Apennine rivers, whose regime is torrential, and in years of particular strong floods such as the one considered here their sediment inputs can be several times higher than the climatological values used in this model. A similar

10 lack of deposition is found in the model results along the western coast north of the Gargano promontory, where a few rivers following again torrential regimes are present, but not realistically considered in the simulation model in terms of flow and sediment contribution. In conclusion, the model simulations show that the very coastal belt of the whole north-western Adriatic Sea is found to be affected by erosion processes.

\subsection{Analysis of sediment transport patterns to events of Bora and Sirocco}

In order to understand the different impacts that Sirocco and Bora winds can have on sediment transport, we have analyzed the mean sediment transport, sediment concentration and currents for $\mathrm{HC} 1$ and DS1events, characterized respectively by Sirocco and a Bora winds. The duration of the two events was approximately of $21 \mathrm{~h}$, and the maximum bottom shear stresses simulated were respectively of $3.8 \mathrm{~Pa}$ and of $3.0 \mathrm{~Pa}$, so the two events can be considered comparable.

The results of the analysis are presented in Figs. 9-11.

Figure 9 shows the modelled depth averaged currents and sediment concentration for the HC1 (left) and DS1 (right) events, where the hourly data have been time25 averaged over the duration of the events, respectively from 13 November 2002 at 11:00 p.m. to 14 November 2002 at 07:00 p.m., and from 7 January 2003 at 00:00 to 7 January 2003 at 08:00 p.m.
OSD

$11,1391-1433,2014$

Numerical modelling of sediment transport in the Adriatic Sea

A. Guarnieri et al.

\section{Title Page}

Abstract Introduction

Conclusions References

Tables Figures

14

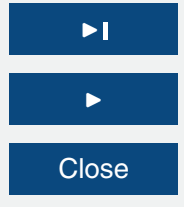

Full Screen / Esc

Printer-friendly Version

Interactive Discussion 
During the event of Sirocco (left panel) the cyclonic circulation of the northern Adriatic is weakened by the effect of the winds. In particular the very coastal circulation is reversed up the Po river delta, and the transport is northward, contrarily to what happens during the Bora event, when the cyclonic circulation is enhanced and its in5 tensity along the western coast is up to 3-4 times that one reported during Sirocco. Also the distribution of the sediment concentration presents different characteristics: during Sirocco we have a higher concentration all around the Po delta promontory than during Bora, while in the Bora event the high concentrations are localized on a larger coastal strip. Sirocco wind conditions are responsible for a more diffused resuspension 10 of the solid materials. In general, strong Bora events tend to affect the sediment transport of a more confined portion of the northern basin, concentrated along the western coast, and the horizontal gradients of currents, sediment concentrations and horizontal sediment fluxes are much more pronounced, while events of Sirocco tend to smooth them, especially those of sediment concentration.

15 Figures 10 and 11 show what happens in terms of sediment transport along the vertical profile of the water column for the same two events of Bora and Sirocco along section $A$ - a section north of the Po river delta - and section $B$ - the section of the tripod WHOI, south of the Po river delta (see Fig. 1).

In contrast with what happens at section $\mathrm{A}$, the Sirocco $\mathrm{HC} 1$ event causes a signif20 icant reversal of the coastal circulation until longitude $12.5^{\circ} \mathrm{E}$ (see Fig. 11) along the whole water column. This reversal of current combined with the high sediment concentration in the lower part of the water column is responsible for an evident northward transport integrated over the whole section B. At section A the northward flow is only appreciated at the surface, and is more confined to the coast, resulting in a net southward flux integrated on the whole transect. In the case of Bora the concentration of resuspended sediment is lower than in the case of Sirocco, but the resulting integrated fluxes over transects $A$ and $B$ are much bigger. This is because Bora produces a strong enhancement of the cyclonic circulation in particular along the western coast, thus resulting in a strong southward flux of sediment, both at section $A$ and $B$.

OSD

$11,1391-1433,2014$

Numerical modelling of sediment transport in the Adriatic Sea

A. Guarnieri et al.

\section{Title Page}

Abstract Introduction

Conclusions References

Tables Figures

14

4

Back

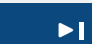

$>$

Close

Full Screen / Esc

Printer-friendly Version

Interactive Discussion 
Table 1 below summarizes the total meridional transports of coarse and fine sediment integrated in time and space for the two events HC1 and DS1 at sections A and B. Positive transport is towards north and negative transport is towards south. The only northward transport is experienced south of the Po river for what concerns the coarse 5 sediment. In general during Bora wind the sediment transport is higher for coarse than for fine sediment in both the sections north and south of the Po river. On the contrary during Sirocco the southward transport is very much weakened, and more fine than coarse sediment is advected through section $A$. At section $B$ we even have a northward flux of the coarse sediment, due to the strong resuspension and northward current very close to coast and along the whole water column (Fig. 11 left panels).

These results essentially agree with the realistic simulations of Bever et al. (2009) in which the temporal variations of the wind field resulted in northward transports during strong Sirocco conditions, and where the export of sediments from the Po river area was very much enhanced during strong Bora events, as also happens in the present study (see Table 1). Comparing to the results of Wang and Pinardi (2002) they also found a reversal of the current in a transect south of the Po River during strong Sirocco, but while in our case it concerns only the western coastal belt (Fig. 11, second and third panels to the left), in their case it extended from west to east along the whole width of the basin, and almost along the whole water column. These differences may be due 20 to the differences in the circulation components of the models, and most likely to their very different horizontal and vertical resolutions.

\section{Summary and conclusions}

In the present paper a baroclinic version of POM with tides coupled with a wave model and a sediment transport sub-model was used to simulate sediment transport pro25 cesses in the Adriatic Sea. The sediment transport sub-model uses the formulation of Wang et al. (2006) with a new bottom sediment fluxes parameterization (Souza et al., 2007). The sediment transport model was embedded within the circulation model, while
OSD

$11,1391-1433,2014$

Numerical modelling of sediment transport in the Adriatic Sea

A. Guarnieri et al.

\section{Title Page}

Abstract Introduction

Conclusions References

Tables Figures

14

4

Back

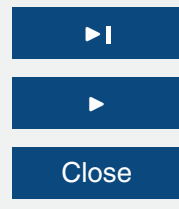

Full Screen / Esc

Printer-friendly Version

Interactive Discussion 
the wave model was coupled off-line through the combined wave-current interaction at the bottom, resulting in an enhancement of the shear stresses. Two classes of sediments were simulated: a finer class with diameter of approximately $17 \mu \mathrm{m}$ and settling velocity $w_{\mathrm{s}}=10^{-5} \mathrm{~m} \mathrm{~s}^{-1}$ and a coarser class with diameter of $55 \mu \mathrm{m}$ and settling ve5 locity $w_{\mathrm{s}}=10^{-4} \mathrm{~m} \mathrm{~s}^{-1}$. The rivers are supposed to supply both classes at the same rate. These simplifying assumptions are most likely the sources of some of the model inaccuracies.

The model has been integrated over a period of one and a half years between August 2002 and December 2003. This period of time includes the big Po river flood of 10 November-December 2002, and other events occurring in the following 2-3 months period where both Bora and Sirocco events occurred. The model has been validated by means of comparison with available data on sediment concentration along the water column at high frequency (hourly), in a very coastal location near the Po river, and by means of comparison with results of similar published studies on these and similar 15 events.

The simulated maximum bottom stresses, compared to those simulated by a 1 dimensional bottom boundary layer model (Wiberg and Smith, 1983; Wiberg et al., 1994) applied in the same period (Traykovski et al., 2007), are quite realistic. The simulated sediment concentrations and fluxes along the water column during autumn 2002 and winter 2003 compare also well with observations showing that the model is capable to represent the major dynamics of sediment transport, and to reproduce well the strong storm events in regions of very strong sediment activities, such as the depocenter around the Po river. However, it is important to note that the simulated sediment fluxes and concentrations would fit much better the observations if we only had considered the coarse sediments. This might also be due to the fact that observations of sediment concentration were measured with acoustic backscatter which is more sensitive to coarser sediment.

The simulated high concentration events (i.e. those events where the near bottom concentration are of the order of magnitude of several $\mathrm{gL}^{-1}$, confined in the first

\section{OSD}

$11,1391-1433,2014$

Numerical modelling of sediment transport in the Adriatic Sea

A. Guarnieri et al.

\section{Title Page}

Abstract Introduction

Conclusions References

Tables Figures

14

4

Back

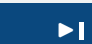

$>$

Close

Full Screen / Esc

Printer-friendly Version

Interactive Discussion 
centimetres above the bottom) are less accurate than the diluted events. The very high near bottom concentrations, within the first $10 \mathrm{~cm}$ a.b., are not well represented by the model and the seabed is depleted of sediments very easily. On the other hand, the sediment vertical mixing seems too strong, and probably the characterization of 5 the sediment grains is not accurate enough. In fact the modelled sediment concentrations along the water column are too homogeneous compared to observations, where we have a much stronger vertical gradient of concentration (values up to $50 \mathrm{~g} \mathrm{~L}^{-1}$ at the bottom and $10^{-3}-10^{-2} \mathrm{~g} \mathrm{~L}^{-1}$ at the surface). This problem is similar to that faced by Traykovski et al. (2007). They found it was partly related to the omission of an ac10 tive layer, and mainly to the absence of a correction accounting for sediment density stratification. In their case the inclusion of such corrections solved the problem of overestimation of sediment concentration above the bottom boundary layer, and amongst them two the most impacting one was the one related to the sediment density stratification. In our case we partly consider the limitation of bottom erosion through the bottom 15 boundary mass conservation condition, so we may think of solving this inaccuracy by including the effect of additional density due to the suspended sediment within the Mellor-Yamada 2.5 mixing scheme. Events DS1 and DS4 are well represented, while DS2 and DS3 are under-estimated. The reason of this underestimation can probably be found in the scarcity of available material for erosion at the beginning of the storms 20 (see Fig. 6).

Beside the concentration of sediments along the water column it is important to focus on the sediment fluxes in the studied domain. These latter depend both on the concentration and on the hydrodynamics velocity fields. A part from hydrodynamics inaccuracies evidenced in events $\mathrm{HC} 2$ and $\mathrm{HC} 3$ when the simulated meridional velocity lative vertically integrated sediment transport, both along and across the shelf in the location of the WHOI tripod.

The results of the model integrations appear to be realistic also in the perspective of accumulation rates, depositional patterns, and sediment pathways in the domain. This 
is very important for all the applications mostly related to a long time-scale approach in sediment transport, such as sediment sea mining for beach feeding, for as example. The three main depocenters of the Adriatic basin (the promontories of the Po river, offshore Ancona, and offshore the end of the Gargano region) are well localized by 5 the model and also the respective simulated accumulation rates over a year period are consistent to what has been observed by Frignani et al. (2005). On the contrary it is to be noticed that the erosive component of the model seems to be too strong in some particular areas of the domain, such as the very coastal Italian region around the line of $44.5^{\circ} \mathrm{N}$, or the near-coast areas along the Gargano region where the local rivers 10 reverse water and sediment into the Adriatic Sea.

In the end, process investigation was conducted in order to understand the different impacts on sediment transport caused by events of Bora and Sirocco. The analysis of the results substantially corroborates previous findings resulting from similar works of the past, in particular those by Wang and Pinardi (2002) and Beaver et al. (2009). 15 We found that strong events of Sirocco may produce northward sediment transport in very coastal areas along the western Adriatic coast, and be responsible of higher values of sediment concentration near the Po river promontory and close to the sea bottom, due to a strong resuspension activity. The sediment transport near the Po areas is increased during episodes of Bora, mainly due to the intensification of the costal current, and is much more relevant in the southern than in the northern vicinities of the Po river mouth. As for the sediment concentration distribution around the domain, it is also different: during Bora events the high sediment concentration is much more confined towards the western coast of the northern Adriatic Sea. Sirocco events, on the contrary, produce a more diffused and spread resuspension of the solid matter, also at deeper topography, and more towards the central part of the northern area of the basin.

In spite of some problems evidenced in the analysis of the results we think the presented model is robust and reliable in the reproduction of sediment transport and concentration in the Adriatic Sea, as proved by the consistence with observations and with

\section{OSD}

11, 1391-1433, 2014

Numerical modelling of sediment transport in the Adriatic Sea

A. Guarnieri et al.

\section{Title Page}

Abstract Introduction

Conclusions References

Tables Figures

14

4

Back

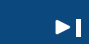

$>$

Close

Full Screen / Esc

Printer-friendly Version

Interactive Discussion 
previous consolidated literature results. We believe that some of the emerged simulation problems could be solved introducing two important corrections to the sediment sub-model, which we want to propose as future work: (i) introduce a variable critical stress of erosion both in time and space, inversely dependent on bathymetry, and di5 rectly dependent on the compacting time of the sediment available for erosion, and (ii) formulate a sea bottom sub-model considering the use of an active layer with variable thickness where the deposited sediment is available for erosion and also related to the granulometry of the solid material.

Acknowledgements. The present work was supported by the European Commission MyOcean 102 Project (FP7-SPACE-2011-1-Prototype Operational Continuity for the GMES Ocean Monitoring and Forecasting Service, GA 283367).

\section{References}

Amoudry, L. and Souza, A. J.: Deterministic coastal morphological and sediment transport modeling: a review and discussion, Rev. Geophys., 49, RG2002, doi:10.1029/2010RG000341, 152011.

Ariathurai, R. and Krone, R. B.: Mathematical modelling of sediment transport in estuaries, Estuarine Processes, 2, 98-106, 1976.

Bever, A. J., Harris, C. K., Sherwood, C. R., and Signell, R. P.: Deposition and flux of sediment from the Po River, Italy: an idealized and wintertime numerical modeling study, Mar. Geol., 260, 69-80, 2009.

Blumberg, A. F. and Mellor, G. L.: A description of a three-dimensional coastal ocean circulation model, in: Three Dimensional Coastal Ocean Models, edited by: Heaps, N. S., American Geophysical Union, Washington, DC, 208 pp., 1987.

Booij, N., Ris, R. C., and Holthuijsen, L. H.: A third-generation wave model for coastal regions,

Part I, Model description and validation, J. Geophys. Res., 104, 7649-7666, 1999.

Cacchione, D. A., Drake, D. E., Kayen, R. W., Sternberg, R. W., Kineke, G. C., and Tate, G. B.: Measurements in the bottom boundary layer on the Amazon subaqueous delta, Mar. Geol., 125, 235-257, 1995.

\section{OSD}

$11,1391-1433,2014$

Numerical modelling of sediment transport in the Adriatic Sea

A. Guarnieri et al.

\section{Title Page}

Abstract Introduction

Conclusions References

Tables Figures

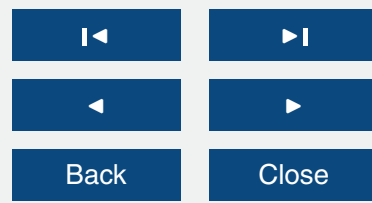

Full Screen / Esc

Printer-friendly Version

Interactive Discussion 
Cavaleri, L. and Bertotti, L.: In search of the correct wind and wave fields in a minor basin, Mon. Weather Rev., 125, 1964-1975, 1997.

Cavaleri, L. and Bertotti, L.: Accuracy of the modelled wind and wave fields in enclosed seas, Tellus A, 56, 167-175, 2004.

5 Estubier, A. and Lévy, M.: Quel schéma numérique pour le transport d'organismes biologiques par la circulation océanique, Note Techniques du Pôle de modélisation, Institut Pierre-Simon Laplace, 18 pp., 2000.

Fain, A. M. V., Ogston, A. S., and Sternberg, R. W.: Sediment transport event analysis on the western Adriatic continental shelf, Cont. Shelf Res., 27, 431-451, 2007.

10 Frascari, F., Frignani, M., Guerzoni, S., and Ravaioli, M.: Sediments and Pollution in the Northern Adriatic Sea, Reprinted from Living in a Chemical World, Vol. 534, 1988.

Frignani, M., Langone, L., Ravaioli, M., Sorgente, D., Alvisi, F., and Albertazzi, S.: Fine-sediment mass balance in the western Adriatic continental shelf over a century time scale, Mar. Geol., 222-223, 113- 133, 2005.

Grant, W. D. and Madsen, O. C.: The continental shelf bottom boundary layer, Annu. Rev. Fluid Mech., 18, 265-305, 1986.

Grant, W. D. and Madsen, O. S.: Combined wave and current interaction with a rough bottom, J. Geophys. Res., 84, 1797-1808, 1979.

Grant, W. D., Williams III, A. J., and Glenn, S. M.: Bottom stress estimates and their prediction on the northern California continental shelf during CODE-I: the importance of wave-current interaction, J. Phys. Oceanogr., 14, 506-527, 1984.

Guarnieri, A., Pinardi, N., Oddo, P., Bortoluzzi, G., and Ravaioli, M.: Impact of tides in a baroclinic circulation model of the Adriatic Sea, J. Geophys. Res.-Oceans, 118, 166-183, doi:10.1029/2012JC007921, 2013.

Harris, C. K. and Wiberg, P. L.: A two-dimensional, time-dependent model of suspended sediment transport and bed reworking for continental shelves, Comput. Geosci., 27, 675-690, 2001.

Harris, C. K. and Wiberg, P. L.: Across-shelf sediment transport: interactions between suspended sediment and bed sediment, J. Geophys. Res., 107, 8.1-8.12, doi:10.1029/2000JC000634, 2002.

Hellerman, S. and Rosenstein, M.: Normal monthly wind stress over the world ocean with error estimates, J. Phys. Oceanogr., 13, 1093-1104, 1983. 
Holthuijsen, L. H., Booij, N., and Herbers, T. H. C.: A prediction model for stationary, shortcrested waves in shallow water with ambient currents, Coast. Eng., 13, 23-54, 1989.

Janssen, P.: Quasi-linear theory of wind wave generation applied to wave forecasting, J. Phys. Oceanogr., 21, 1631-1642, 1991.

5 Kondo, J.: Air-sea bulk transfer coefficients in diabatic conditions, Bound.-Lay. Meteorol., 9, 91-112, 1975.

Legates, D. R. and Wilmott, C. J.: Mean seasonal and spatial variability in a gauge corrected global precipitation, Int. J. Climatol., 10, 121-127, 1990.

Lou, J., Schwab, D. J., Belesky, D., and Hawley, N.: A model of sediment resuspension and transport dynamics in southern Lake Michigan, J. Geophys. Res., 105, 6591-6610, 2000.

Madsen, O. S., Poon, Y.-K., and Graber, H. C.: Spectral wave attenuation by bottom friction: theory. in: Proceedings of the 21th International conference on Coastal Engineering, ASCE, New York, 492-504, 1988.

Marini, M., Grilli, F., Guarnieri, A., Jones, B. H., Kljajic, Z., Pinardi, N., and Sanxhaku, M.: Is 15 the south-eastern Adriatic Sea coastal strip an eutrophic area?, Estuar. Coast. Shelf S., 88, 395-406, 2010.

May, P. W.: A brief explanation of Mediterranean heat and momentum flux calculations, NORDA Code 322, available from Nav Oceanogr Atmos Res Lab, NTSL station, Ms 39529, 1986.

Mellor, G.: An equation of state for numerical models of ocean and estuaries, J. Atmos. Ocean. Tech., 8, 609-612, 1991.

Oddo, P. and Pinardi, N.: Lateral open boundary conditions for nested limited area models: process selective approach, Ocean Model., 20, 134-156, 2008.

Palinkas, C. M., Nittrouer, C. A., Wheatcroft, R. A., and Langone, L.: The use of 7Be to identify event and seasonal sedimentation near the Po River delta, Adriatic Sea, Mar. Geol., 222223, 95-112, 2005.

Pinardi, N., Allen, I., Demirov, E., De Mey, P., Korres, G., Lascaratos, A., Le Traon, P. Y., Maillard, C., Manzella, G., and Tziavos, C.: The mediterranean ocean forecasting system: first phase of implementation (1998-2001), Ann. Geophys.-Italy, 21, 3-20. 2003.

Ravaioli, M., Albertazzi, S., Mercuriali, C., and Marozzi, G.: "Bioturbazione e velocità di sedimentazione", in: Report di fine attività U.O. I.G.M.-C.N.R., Sottoprogetto "Valutazione dei carichi esegeni: Flussi da e verso i fondali" - PRISMA 1 (Programma di Attività e Sperimentazione per la Salvaguardia del Mar Adriatico - fase 1), 58 pp., 1997.

\section{OSD}

$11,1391-1433,2014$

Numerical modelling of sediment transport in the Adriatic Sea

A. Guarnieri et al.

\section{Title Page}

Abstract Introduction

Conclusions References

Tables Figures

14

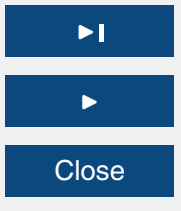

Back

Close

Full Screen / Esc

Printer-friendly Version

Interactive Discussion 
Ris, R. C., Booij, N., and Holthuijsen, L. H.: A third-generation wave model for coastal regions, Part II: Verification, J. Geophys. Res.-Oceans., 104, 7667-7681, 1999.

Sanford, L. P. and Halka, J. P.: Assessing the paradigm of mutually exclusive erosion and deposition of mud, with examples from upper Chesapeake bay, Mar. Geol., 114, 37-57, 1993.

5 Smagorinsky, J.: Some historical remarks on the use of nonlinear viscosities, in: Large Eddy Simulations of Complex Engineering and Geophysical Flows, edited by: Galperin, B. and Orszag, S., Cambridge Univ. Press, New York, 3-36, 1993.

Smith, J. D.: Modeling of Sediment Transport on Continental Shelves, The Sea, WileyInterscience, New York, 1977.

10 Souza, A. J., Holt, J. T., and Proctor, R.: Modelling SPM on the NW European shelf seas, from Balson, P. S. and Collins, M. B., Coastal and Shelf Sediment Transport, Geological Society of London, Special Publications, 274, 147-158, 2007.

SWAN Team: SWAN Scientific and Technical Documentation, SWAN Cycle III version 40.81, Delft University of Technology, 2010.

Tonani, M., Pinardi, N., Dobricic, S., Pujol, I., and Fratianni, C.: A high-resolution free-surface model of the Mediterranean Sea, Ocean Sci., 4, 1-14, doi:10.5194/os-4-1-2008, 2008.

Traykovski, P., Wiberg, P. L., and Geyer, W. R.: Observations and modeling of wave-supported sediment gravity flows on the Po prodelta and comparison to prior observations from the Eel shelf, Cont. Shelf Res., 27, 375-399, 2007.

20 Vichi, M., Pinardi, N., Zavatarelli, M., Matteucci, G., Marcaccio, M., Bergamini, M. C., and Frascari, F.: One-dimensional ecosystem model tests in the Po Prodelta area (Northern Adriatic Sea), Environ. Modell. Softw., 13, 471-481, 1998.

Wang, X. H. and Pinardi, N.: Modeling the dynamics of sediment transport and resuspension in the northern Adriatic Sea, J. Geophys. Res., 107, 18-1-18-23, doi:10.1029/2001JC001303, 2002.

Wang, X. H., Pinardi, N., and Malacic, V.: Sediment transport and resuspension due to combined motion of wave and current in the northern Adriatic Sea during a Bora event in January 2001: a numerical modeling study, Cont. Shelf Res., 27, 613-633, 2007.

Warren, R. and Johnsen, J.: Cohesive sediment modelling for coastal lagoons, paper presented 30 at International Colloquium and Exposition on Computer Applications in Coastal and Offshore Engineering (ICE-CA COE'93), Kuala Lumper, Malaysia, 14-16 June, 1993.

Wiberg, P. and Smith, J. D.: A comparison of field data and theoretical models for wave-current interactions at the bed on the continental shelf, Cont. Shelf Res., 2, 147-162, 1983.
OSD

11, 1391-1433, 2014

Numerical modelling of sediment transport in the Adriatic Sea

A. Guarnieri et al.

\section{Title Page}

Abstract Introduction

Conclusions References

Tables Figures

14

4

Back

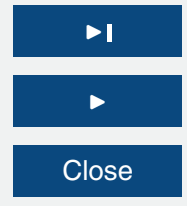

Full Screen / Esc

Printer-friendly Version

Interactive Discussion 
Wiberg, P. L., Drake, D. E., and Cacchione, D. A.: Sediment resuspension and bed armoring during high bottom stress events on the northern California continental shelf: measurements and predictions, Cont. Shelf Res., 14, 1191-1219, 1994.

Winterwerp, J. C. and Van Kesteren, W. G. M.: Introduction to the Physics of Cohesive Sediment $5 \quad$ in the Marine Environment, 56, Elsevier B.V., Amsterdam, the Netherlands, 466 pp., 2004.

\section{OSD}

$11,1391-1433,2014$

Numerical modelling of sediment transport in the Adriatic Sea

A. Guarnieri et al.

\section{Title Page}

Abstract Introduction

Conclusions

References

Tables

Figures

14

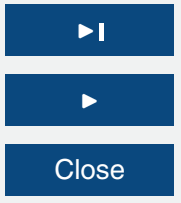

Back

Close

Full Screen / Esc

Printer-friendly Version

Interactive Discussion 
Table 1. Total meridional transport of sediment integrated in space and time along the transects of section A and B during the events of Bora (DS1) and Sirocco (HC1). Values are tons.

\begin{tabular}{lrlrlr}
\hline & \multicolumn{4}{c}{ EVENT } \\
\cline { 3 - 6 } & \multicolumn{2}{c}{ HC1 (Sirocco) } & \multicolumn{2}{c}{ DS1 (Bora) } \\
\hline SECTION & A & Coarse Sediment: & $-994 \mathrm{t}$ & Coarse Sediment: & $-6246 \mathrm{t}$ \\
& & Fine Sediment: & $-1427 \mathrm{t}$ & Fine Sediment: & $-3127 \mathrm{t}$ \\
& B & Coarse Sediment: & $3671 \mathrm{t}$ & Coarse Sediment: & $-25894 \mathrm{t}$ \\
& & Fine Sediment: & $-798 \mathrm{t}$ & Fine Sediment: & $-9887 \mathrm{t}$ \\
\hline
\end{tabular}

OSD

$11,1391-1433,2014$

Numerical modelling of sediment transport in the Adriatic Sea

A. Guarnieri et al.

Title Page

Abstract

Introduction

Conclusions

References

Tables

Figures

14

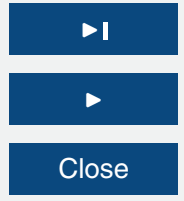

Back

Close

Full Screen / Esc

Printer-friendly Version

Interactive Discussion 


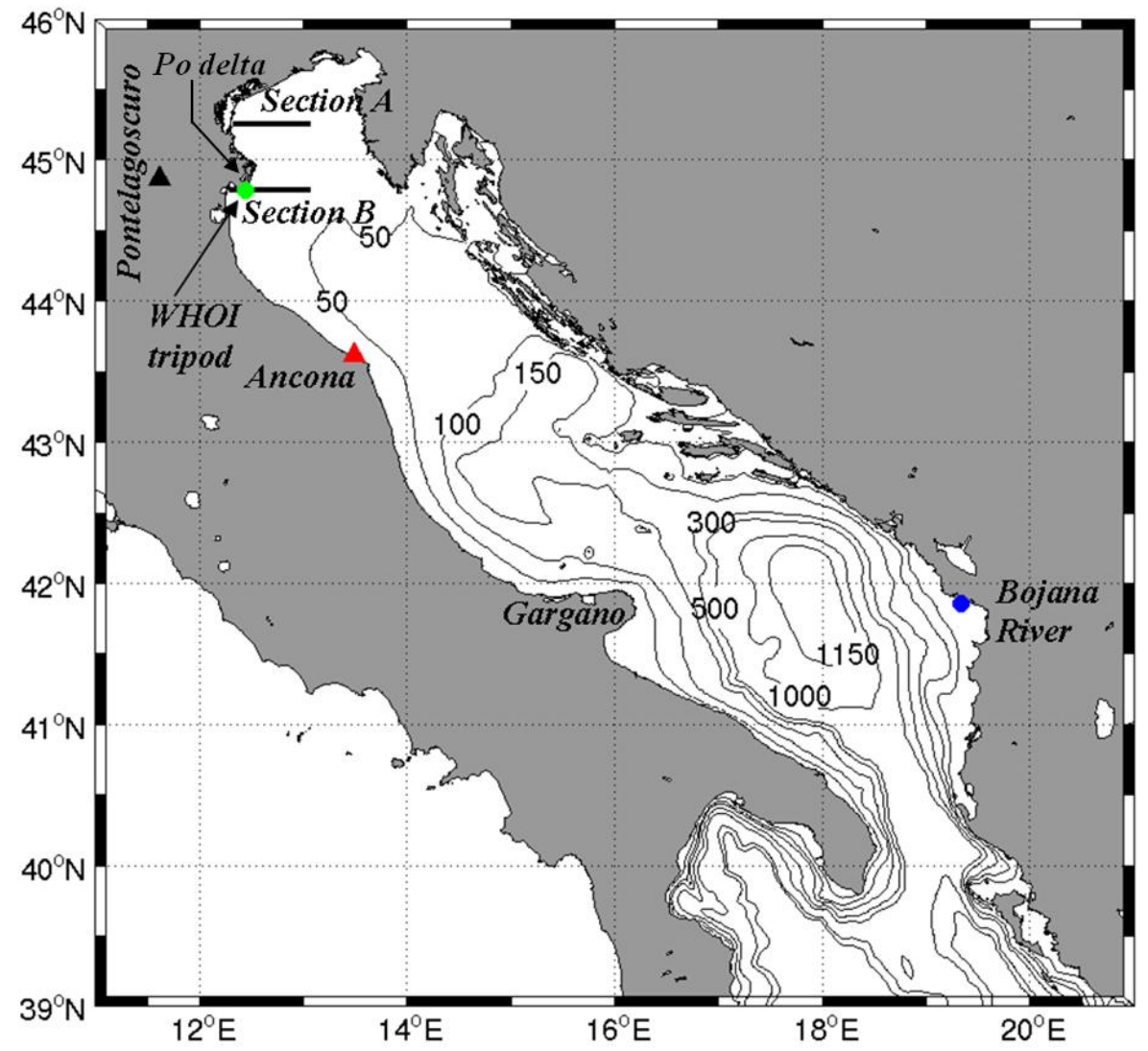

OSD

11, 1391-1433, 2014

Numerical modelling of sediment transport in the Adriatic Sea

A. Guarnieri et al.

\section{Title Page}

\section{Abstract}

Introduction

Conclusions

References

Tables

Figures

14

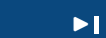

Back

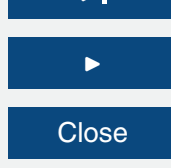

Full Screen / Esc

Printer-friendly Version

Interactive Discussion

Figure 1. Model domain and bathymetry. 


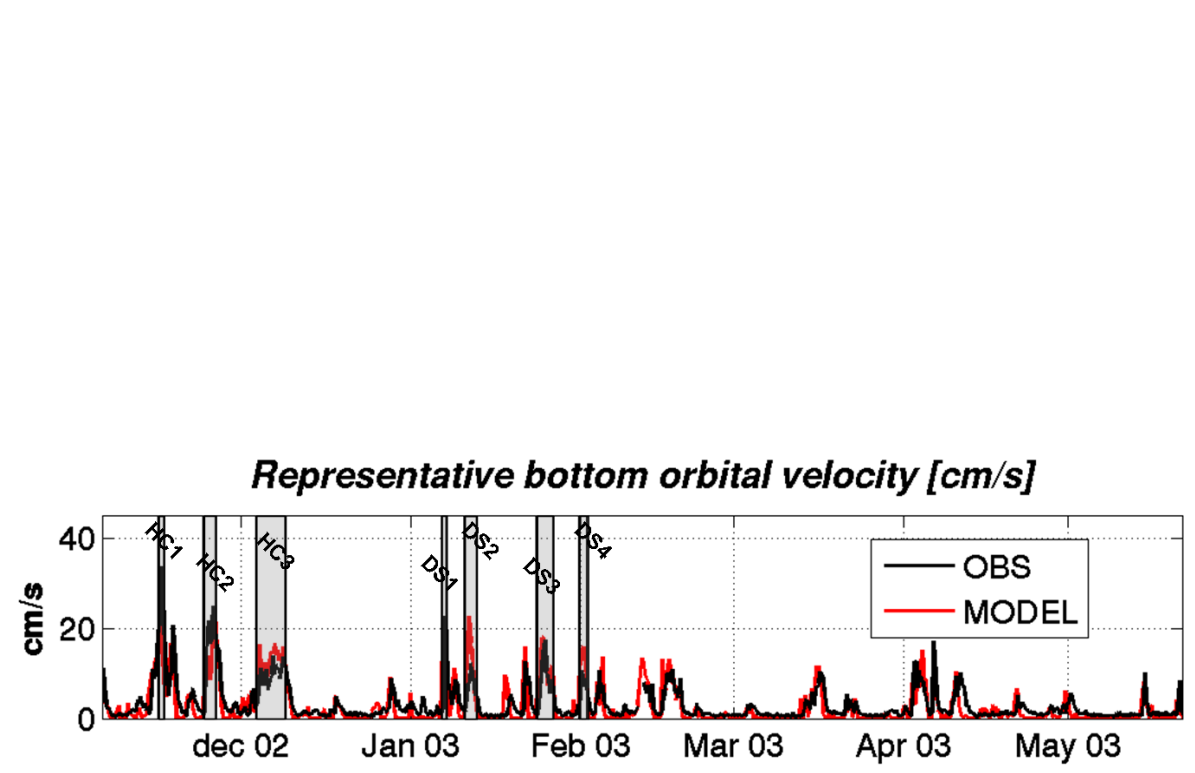

OSD

$11,1391-1433,2014$

Numerical modelling of sediment transport in the Adriatic Sea

A. Guarnieri et al.

\section{Title Page}

Abstract

Introduction

Conclusions

References

Tables

Figures

Figure 2. Validation of the representative bottom orbital velocity (as defined by Madsen, 1979). The black line represents observations, while the red line represents simulations. HC and DS refer respectively to high sediment concentration (turbidity flow) and diluted sediment suspension events, classified by Traykovski et al. (2007).

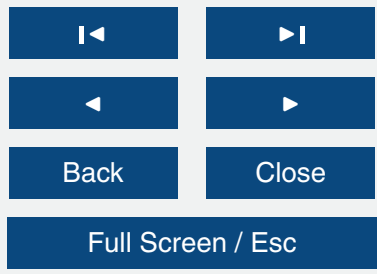

Printer-friendly Version

Interactive Discussion 


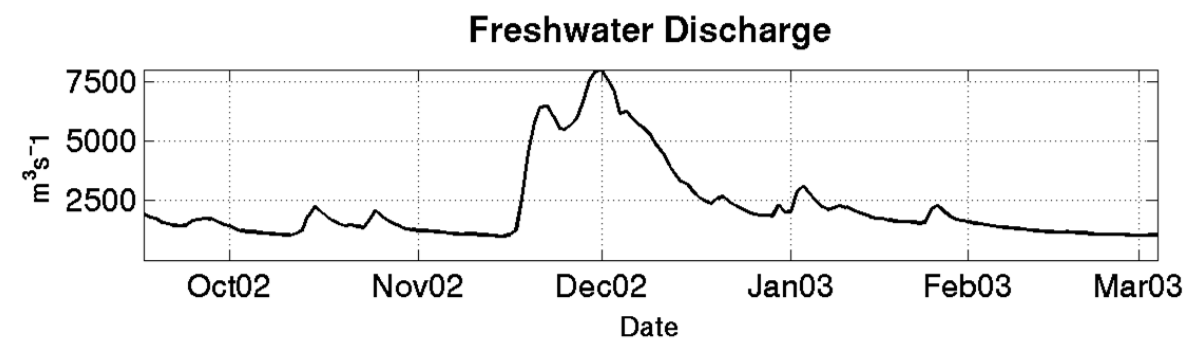

\section{OSD}

$11,1391-1433,2014$

Numerical modelling of sediment transport in the Adriatic Sea

A. Guarnieri et al.

\section{Title Page}

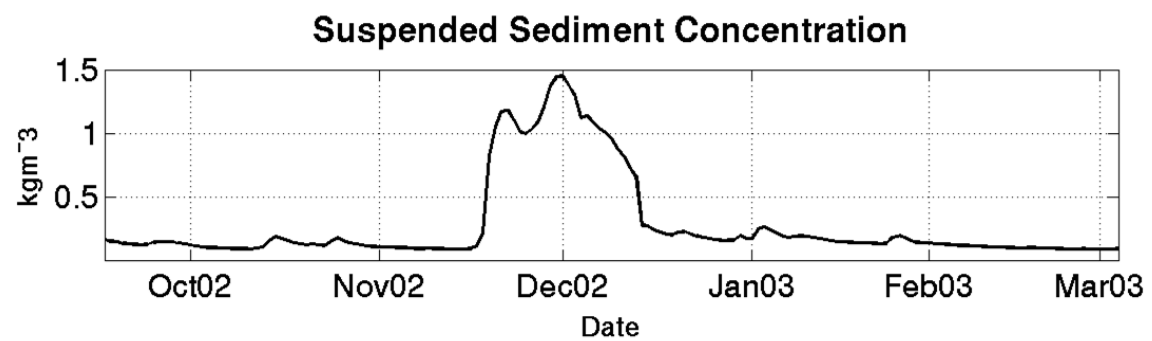

Figure 3. Flow (top panel) and sediment concentration (bottom panels) conditions in the Po river delta, from October 2002 to March 2003. The flow data are observations at Pontelagoscuro (Fig. 1). The sediment concentrations of the second panel are obtained by a numerical model (see Bever et al., 2009, Fig. 2).

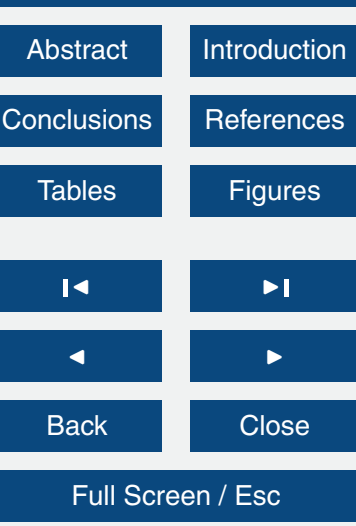

Printer-friendly Version

Interactive Discussion 


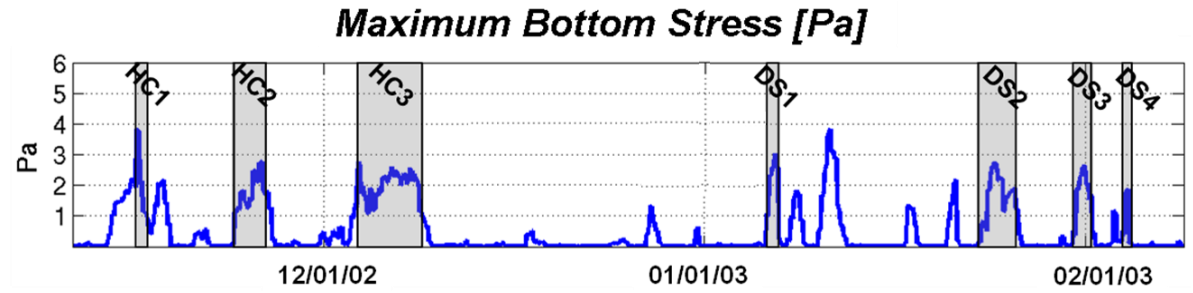

Figure 4. The blue line represents the bottom shear stress $(\mathrm{Pa})$ at the location of the WHOI tripod as simulated by our model. The shaded area shows the timing and duration of the most important events in the perspective of sediment transport.

OSD

$11,1391-1433,2014$

Numerical modelling of sediment transport in the Adriatic Sea

A. Guarnieri et al.

\section{Title Page}

\section{Abstract}

Introduction

Conclusions

References

Tables

Figures

14

4

Back

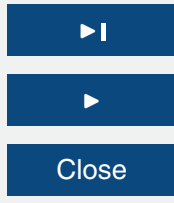

Full Screen / Esc

Printer-friendly Version

Interactive Discussion 

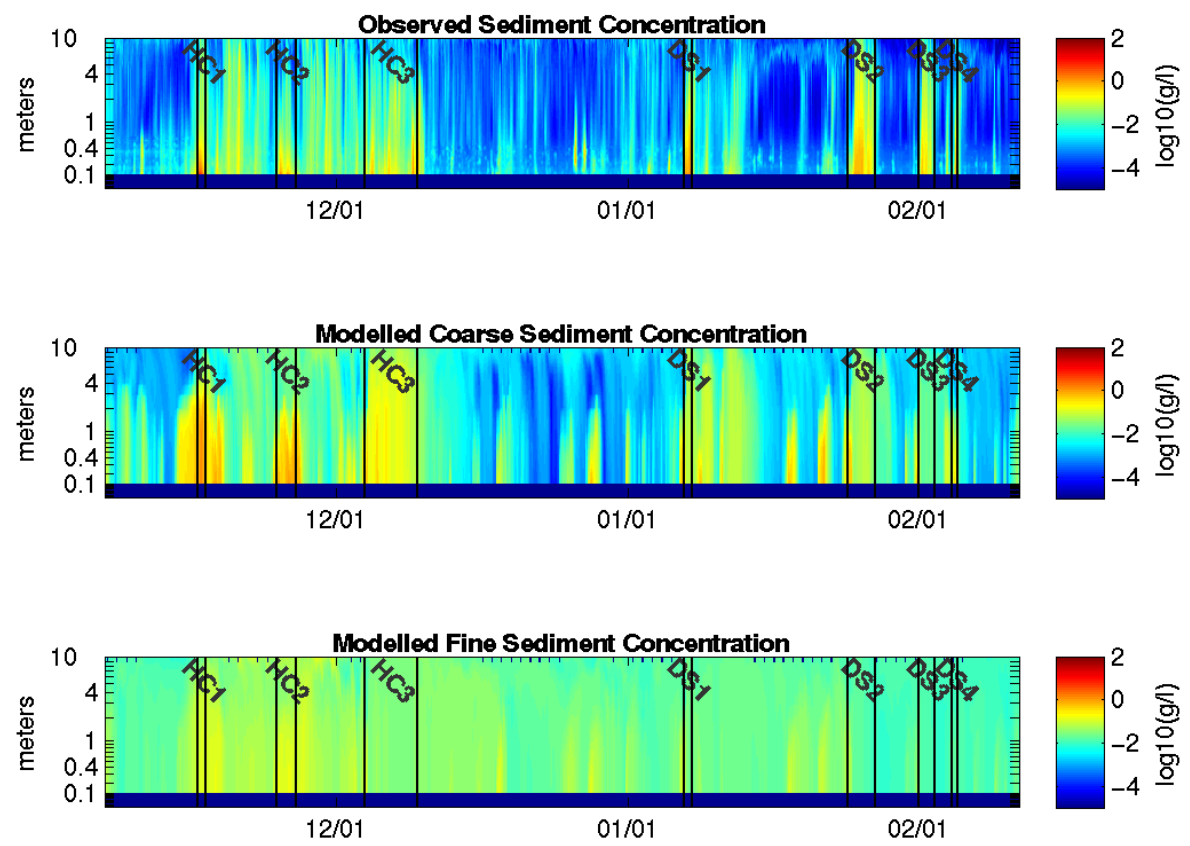

Figure 5. Concentration along the water column for the period November 2002-February 2003. Upper panel: observed sediment concentration data at WHOI tripod (Traykovski et al., 2007). Mid panel: modelled coarse sediment concentration. Bottom panel: modelled fine sediment concentration.
OSD

$11,1391-1433,2014$

Numerical modelling of sediment transport in the Adriatic Sea

A. Guarnieri et al.

\section{Title Page}

\section{Abstract}

Introduction

Conclusions

References

Tables

Figures

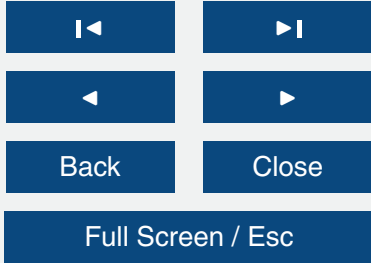

Printer-friendly Version

Interactive Discussion 
OSD

11, 1391-1433, 2014

Numerical modelling of sediment transport in the Adriatic Sea

A. Guarnieri et al.

\section{Title Page}

\section{Abstract}

Introduction

Conclusions

References

Tables

Figures

Figure 6. Evolution of the sea bottom in terms of mass of sediment per square meter $\left(\mathrm{kg} \mathrm{m}^{-2}\right)$ simulated by the model at WHOI tripod location during the period November 2002February 2003. Data are hourly averaged.

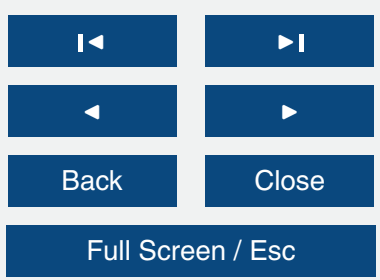

Printer-friendly Version

Interactive Discussion 


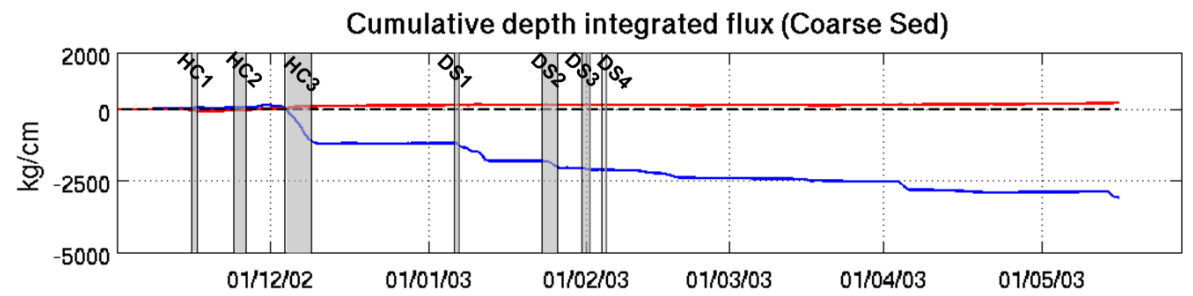

OSD

$11,1391-1433,2014$

Numerical modelling of sediment transport in the Adriatic Sea

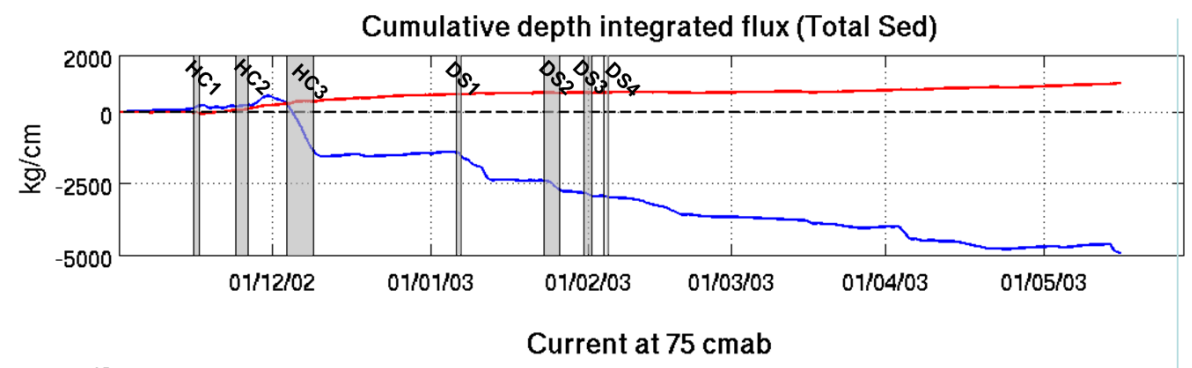

\section{A. Guarnieri et al.}

\section{Title Page}

\section{Abstract}

Introduction

Conclusions

References

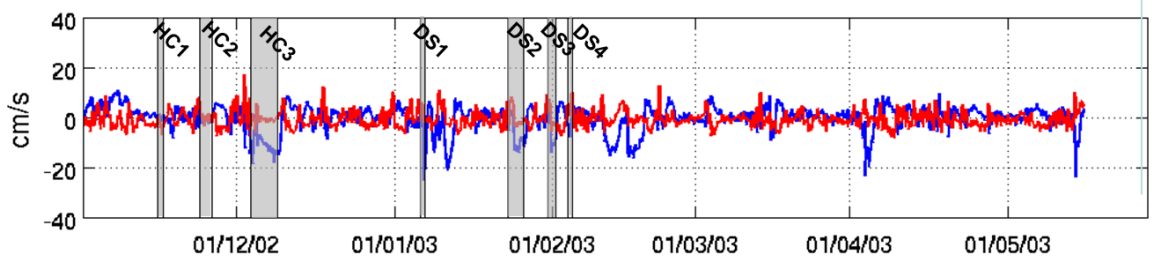

Figure 7. Depth integrated sediment flux (first two panels: coarse top and total middle) and currents at $75 \mathrm{~cm}$ a.b. (bottom panel) simulated by the model at the WHOI tripod location. The investigated period is from November 2002 to May 2003. The top panel shows the coarse sediment, while the mid one shows the total suspended sediment. The bottom panel represents the de-tided current regime. The red and blue lines represent respectively the zonal and meridional components of the analyzed parameters.

\section{Figures}

14

4

Back

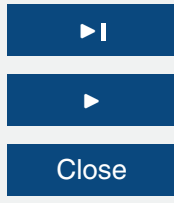

Full Screen / Esc

Printer-friendly Version

Interactive Discussion 


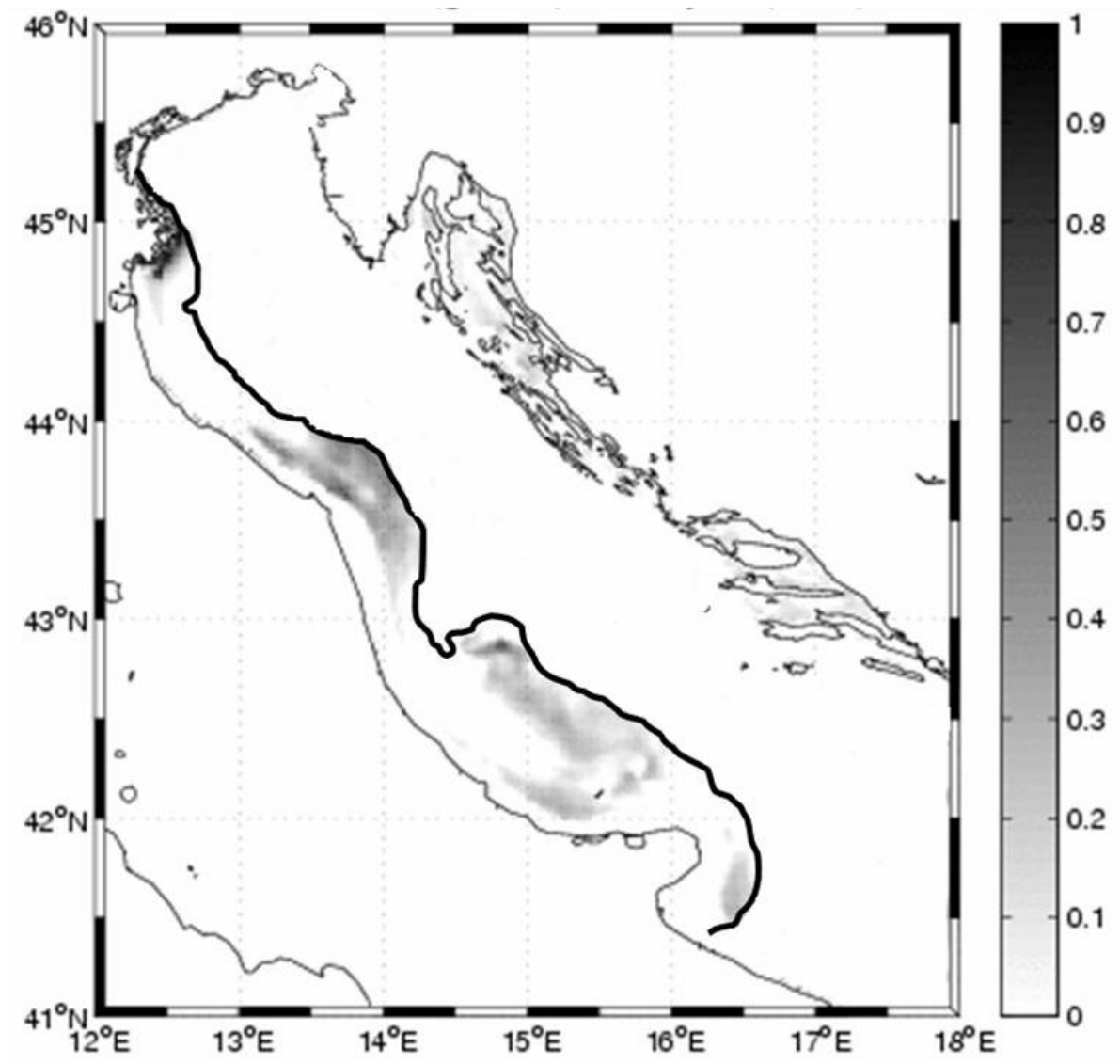

OSD

11, 1391-1433, 2014

Numerical modelling of sediment transport in the Adriatic Sea

A. Guarnieri et al.
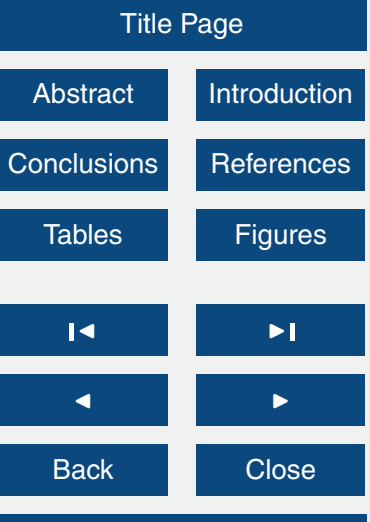

Full Screen / Esc

Printer-friendly Version

Interactive Discussion

Figure 8. Simulated accumulation rate of sediment $\left(\mathrm{g} \mathrm{cm}^{-2} \mathrm{yr}^{-1}\right)$. 

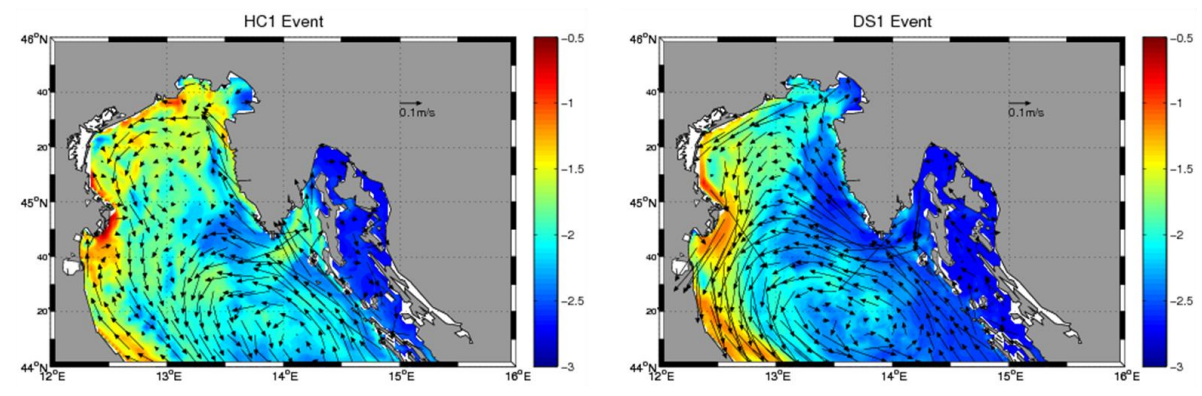

Figure 9. Modelled depth averaged currents (black arrows) and logarithm of sediment concentration $\left(\mathrm{g} \mathrm{L}^{-1}\right)$ for the $\mathrm{HC} 1$ and DS1 events. The hourly modelled data have been time-averaged over the duration of the events.

\section{OSD}

$11,1391-1433,2014$

Numerical modelling of sediment transport in the Adriatic Sea

A. Guarnieri et al.

\section{Title Page}

Abstract

Introduction

Conclusions

References

Tables

Figures

14

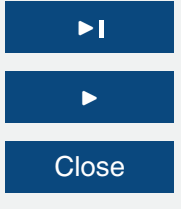

Full Screen / Esc

Printer-friendly Version

Interactive Discussion 

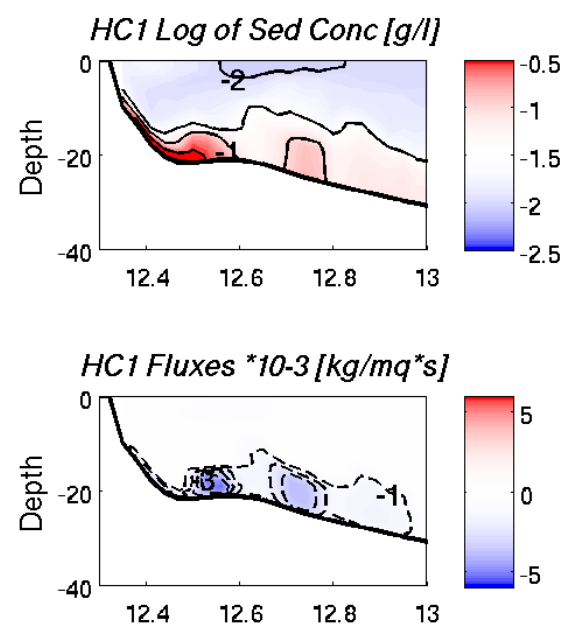

$\mathrm{HCl} \mathrm{Mer} \mathrm{Vel}[\mathrm{cm} / \mathrm{s}]$

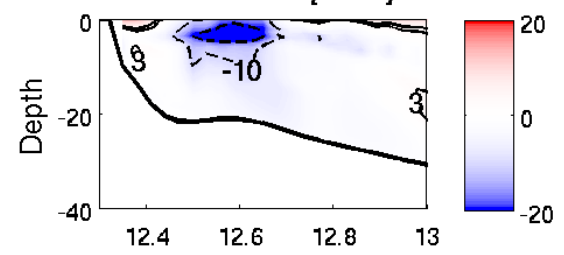

DS1 Log of Sed Conc [g/l]
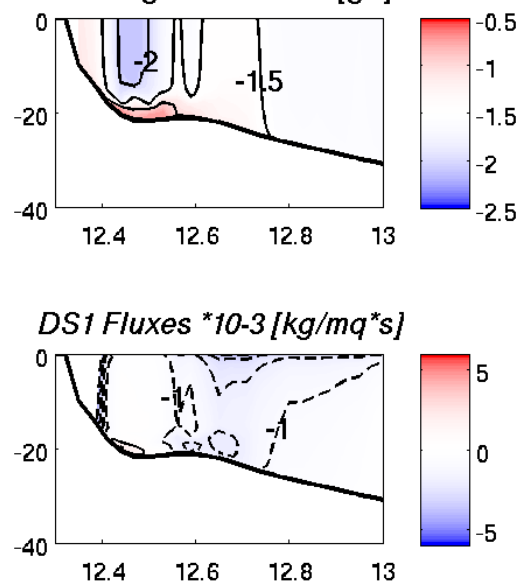

DS1 Mer $\mathrm{Vel}[\mathrm{cm} / \mathrm{s}]$

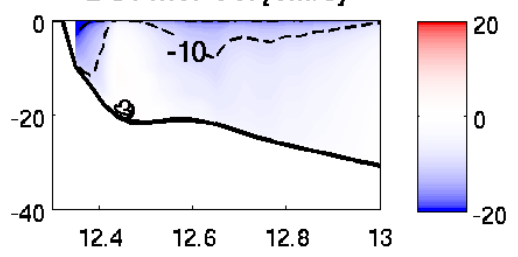

OSD

11, 1391-1433, 2014

Numerical modelling of sediment transport in the Adriatic Sea

A. Guarnieri et al.

\section{Title Page}

\section{Abstract}

Introduction

Conclusions

References

Tables

Figures

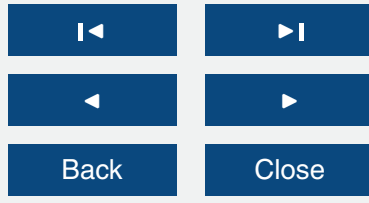

Full Screen / Esc

Printer-friendly Version

Interactive Discussion 


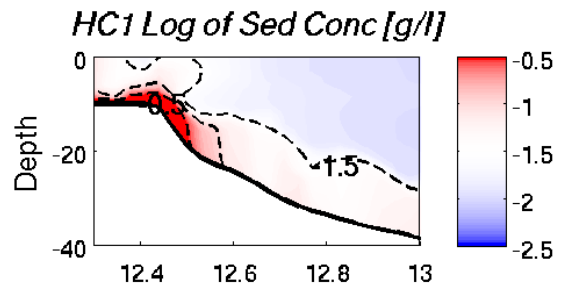

HC1 Fluxes *10-3 [ $\mathrm{kg} / \mathrm{mq}^{*}$ s]
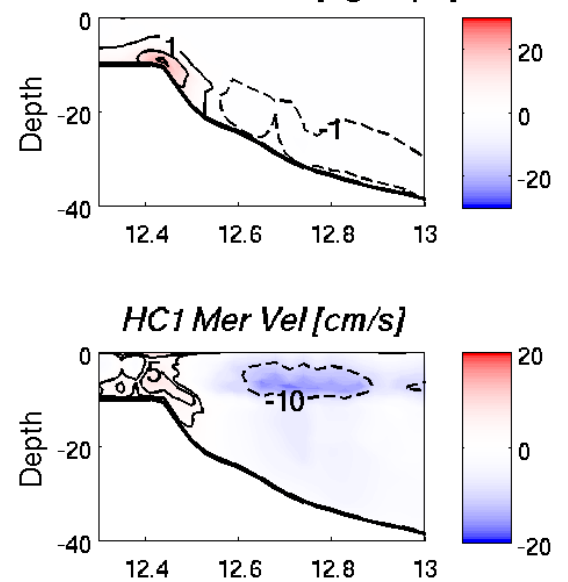

\section{DS1 Log of Sed Conc [g/l]}

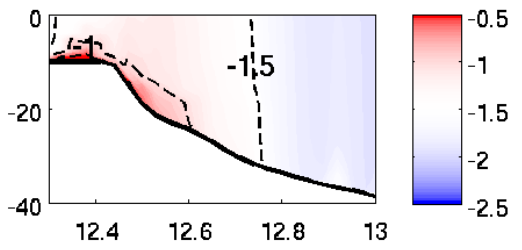

DS1 Fluxes *10-3 $\left[\mathrm{kg} / \mathrm{mq}^{*} \mathrm{~s}\right]$
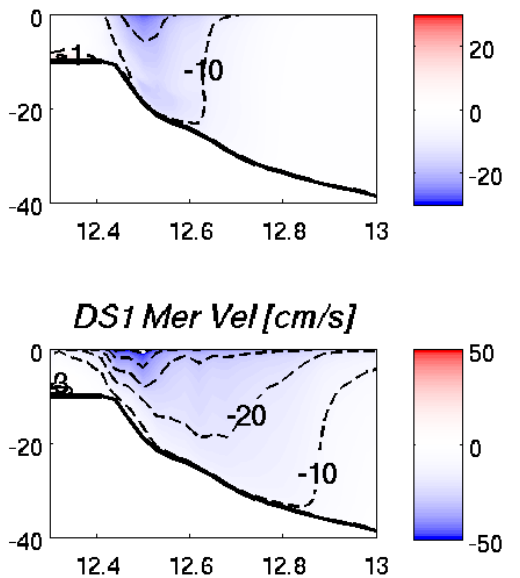

OSD

11, 1391-1433, 2014

Numerical modelling of sediment transport in the Adriatic Sea

A. Guarnieri et al.

\section{Title Page}

\section{Abstract}

Introduction

Conclusions References

Tables

Figures

14

4

Back

Close

Full Screen / Esc

Printer-friendly Version

Interactive Discussion 